\title{
The FOMC in 1978: Clarifying the Role of the Aggregates
}

\author{
RICHARD W. LANG
}

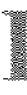
N its policy deliberations in 1978, the Federal Open Market Committee (FOMC) clarified the roles that the monetary aggregates play in policy considerations in two respects. The interpretation and emphasis to be placed on the FOMC's two-month growth ranges of the monetary aggregates were clarified by changes in the wording of the domestic policy directive. The Committee also clarified the role of the growth ranges of the narrowly-defined money stock (M1), relative to the growth ranges of the more broadly-defined monetary aggregates during the transition to the new automatic transfer service (ATS) between checking and savings accounts.
\end{abstract}

This article discusses these clarifications, and reviews the decisions of the FOMC in 1978. Table I summarizes the FOMC's domestic policy directives in 1978. A Supplement at the end of the article presents excerpts from the monthly "Record of Policy Actions of the FOMC" that provide a more detailed meeting-by-meeting summary of FOMC discussions.

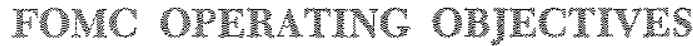 IN 1978}

The Federal Reserve Reform Act of 1977 required the Board of Governors of the Federal Reserve System to consult with committees of the Congress on a quarterly basis in 1978 about the System's objectives and plans for the ranges of growth of monetary and

Note: Unless specified otherwise, citations throughout this article are from either the "Record of Policy Actions of the Federal Open Market Committee" or "Statements to Congress," Federal Reserve Bulletin (February 1978 through Febniary 1979 ). credit aggregates over the next twelve months. Such consultations began in 1975 at the request of Congress as expressed in House Concurrent Resolution 133.

Chairman G. William Miller met with Congressional committees on March 9, April 25, July 28, and November 16,1978 to present the one-year growth ranges of the monetary aggregates (M1, M2 and M3) adopted at the previous FOMC meeting. These annual ranges are based on the quarterly average for the most recent quarter to the quarterly average one year later (see Charts I and II, and Table I). The FOMC has emphasized repeatedly that these one-year ranges are "subject to reconsideration at any time as conditions warrant" 1 and that "short-run factors might cause growth rates from month to month to fall outside the ranges contemplated for the year ahead."'2

An allowance for "short-run factors" that might affect M1 and M2 is reflected in the shorter-run growth ranges set by the FOMC each month. The two-month ranges for both $\mathrm{M} 1$ and $\mathrm{M} 2$ were, with one exception, consistently wider than the longer-run ranges in 1978 . These short-run ranges are believed to be consistent with the longer-run growth ranges, and are specified over moving two-month periods. For example, the FOMC at its January meeting specified short-run ranges for $\mathrm{M} 1$ and $\mathrm{M} 2$ over the January-February period..$^{3}$ At the February meeting the FOMC set new

1"Record" (April 1978), p. 302.

2Ibid., p. 299.

a Since the FOMC usually met in mid-month in 1978 , these two-month ranges are typically set when a quarter of the two month period is over. 


\section{Organization of the Committee in 1978}

The Federal Open Market Committee (FOMC) consists of the seven members of the Federal Reserve Board of Governors and five of the twelve Federal Reserve Bank Presidents. The Chairman of the Board of Governors is also, by tradition, Chairman of the Committee. The President of the New York Federal Reserve Bank is a permanent member of the Committee and, also by tradition, its Vice Chairman. All Federal Reserve Bank Presidents attend the meetings and present their views, but only those Presidents who are members of the Committee may cast votes. Four mem berships rotate among the Bank Presidents and are held for one-year terms beginning March 1.

Members of the Board of Governors at the beginning of 1978 included Chairman Arthur F. Burns, Vice Chairman Stephen S. Gardner, Phillip E. Coldwell, Phillip C. Jackson, Jr., David M. Lilly, J. Charles Partee, and Henry $C$. Wallich. In addition to Patl $A$. Volcker, President of the Federal Reserve Bank of New York, the following Presidents served on the Committee during January and February 1978: Roger Guffey (Kansas City), Robert P. Mayo (Chicago), Frank E. Morris (Boston), and Lawrence K. Roos (St. Louis), In March, G. William Miller succeeded Mr. Burns as Chairman. The Committee was reorganized in March and the four rotating positions were flled by: Ernest T. Baughman (Dallas), David P. Eastburn (Philadelphia), Mark H. Willes (Minneapolis), and Willis I. Winn (Cleveland). Chairman Miller succeeded Mr. Lilly, whose term had expired, as a member of the Board. After the resignation of $\mathrm{Mr}$. Burns from the Board at the end of March, Mrs. Nancy H. Teeters succeded him as a member of the Board in September. During November two vacancies occurred on the Board as a result of the death of Vice Chairman Gardner and the resignation of Mr. Jackson. These positions remained open for the remainder of 1978.

The Committee met monthly during 1978 to discuss, among other things, economic trends and to decide upon the future course of open market operations. However, as in previous years, occasional telephone or telegram consultations were held between schedaled meetings. ${ }^{1}$ During each regularly scheduled meeting, a directive was issued to the Federal Reserve Bank of New York. Each directive contained a short review of economic developments, the general economic goals sought by the Committee, and instructions to the Manager of the System Open Market Account at the New York Bank for the conduct of open market operations. These instructions were stated in terms of money market conditions and short-term rates of growth of $M 1$ and M2 which were considered to be consistent with

\footnotetext{
1 Consultations were held on March 10, May 5, June 16, September 8, October 31, December 8, and December 29 1978 to consider modifying inter-meeting ranges for the Federal funds rate.
}

desired longer-run growth rates of the monetary aggre gates. Special factors, such as conditions in domestic financial markets and foreign exchange markets, were also taken into account.

The Manager makes all decisions regarding the exact timing and amount of daily buying and selling of securities in fulfilling the Committee's directive. Each morning the Manager and his staff plan the open market operations for that day. This plan is developed on the basis of the Committee's objectives for money and credit market conditions, monetary aggregate growth, and other factors which may be of concern to the Committee. The Account Manager, in a conference call, then informs one voting President and staff members of the Board of Govemors about present market conditions and open market operations that he proposes to execute that day. Other members of the Committee are informed of the daily plan by wire.

A summary of the Committee's actions is presented to the public in the "Record of Policy Actions of the Federal Open Market Committee." The "Record" is released a few days after the following FOMC meeting. Soon after its release, the "Record" appears in the Federal Reserve Bulletin and, in addition, "Records" for the entire year are published in the Annual Report of the Board of Governors. The "Record" for each meeting during 1978 generally included:

1) A staff summary of recent economic developments, such as prices, employment, industrial production, and components of the national income accounts; and projections of real output growth for the year ahead;

2) A summary of recent international financial developments and the U.S. foreign trade balance;

3) A summary of recent credit market conditions and recent interest rate movements;

4) A summary of open market operations, the growth of monetary aggregates, and bank reserve and money market conditions since the previous meeting;

5) A summary of the Committee's discussion of current and prospective economic and financial conditions and of current policy considerations, including money market conditions and the movement of monetary aggregates;

6) Conclusions of the FOMC;

7) A policy directive issued by the Committee to the Federal Reserve Bank of New York;

8) A list of the members' voting positions and any dissenting comments;

9) A description of any actions and consultations that may have occurred between the regularly scheduled meetings. 


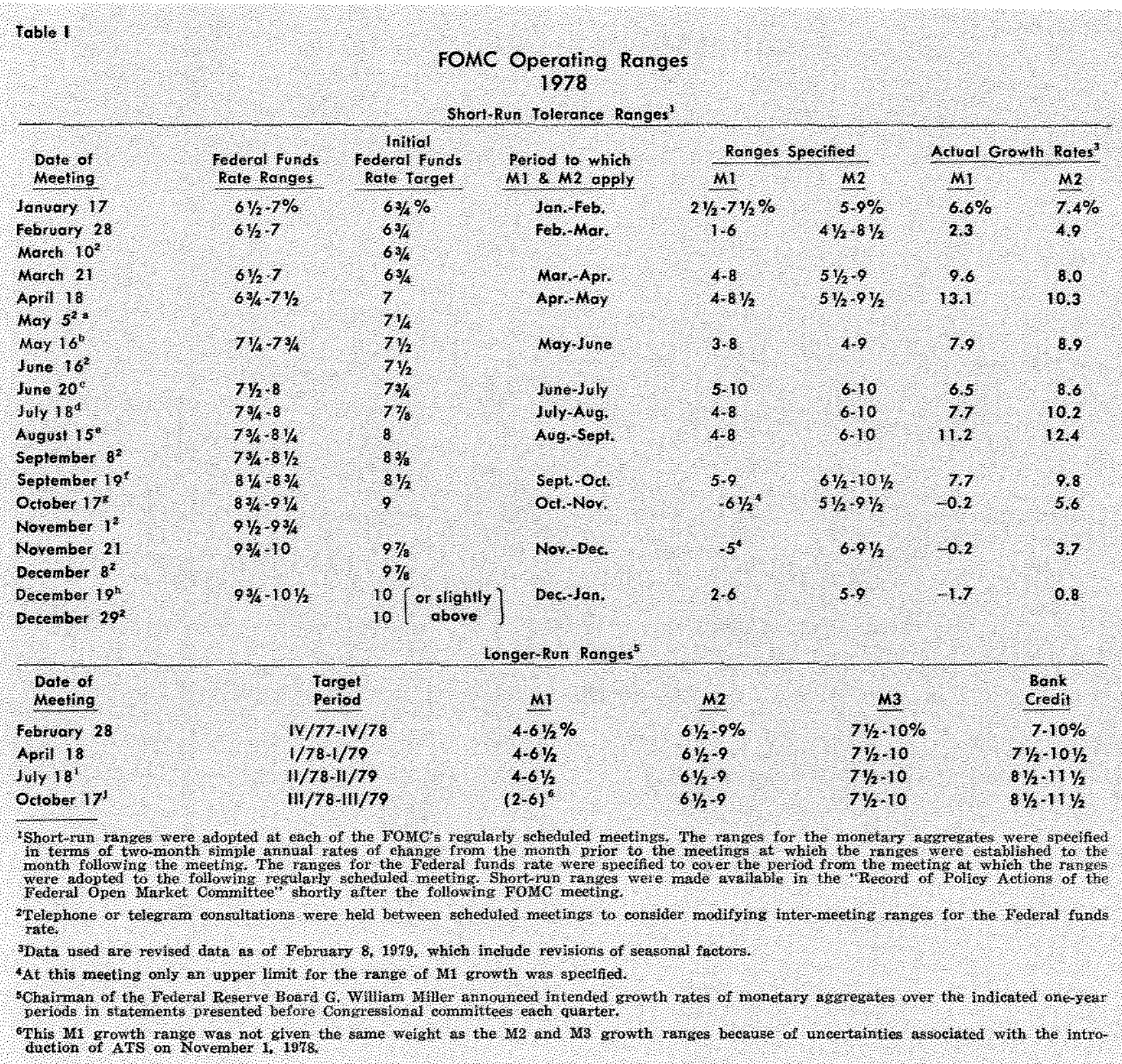

ranges for the February-March period. The twomonth and one-year ranges adopted during 1978 are shown in Table I.

\section{Short-Run Ranges: Clarifying the Directive}

At each monthly meeting, the FOMC sets an intermeeting range for the Federal funds rate along with the two-month ranges for M1 and M2 growth. Within that range, the Committee's objective for the Federal funds rate is stated in terms of a specific level that is thought to be consistent with the short-run ranges set for MI and M2. If the two-month growth rates of MI and M2 appear to be deviating in specified ways from their respective ranges, the domestic policy directive provides that the Federal funds rate objective can be changed within its range, or the range itself can be reconsidered by the Committee.

Prior to the June 20, 1978 meeting, the wording of the domestic policy directives followed the same two general formats as in $\mathbf{1 9 7 7}$ in terms of specifying the relationship between the two-month growth ranges of $\mathrm{M} 1$ and $\mathrm{M} 2$ and the Federal funds rate objective. One format, called an "aggregates directive," indicated that over the inter-meeting period greater weight was to be given to $\mathrm{M} 1$ and $\mathrm{M} 2$ growth than to money market conditions. The other format, called a 
roble $(\mathrm{coninued}$

\section{Supplementary Footnotes:}

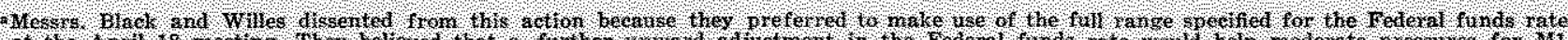

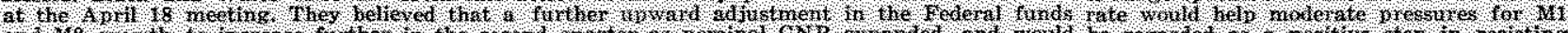

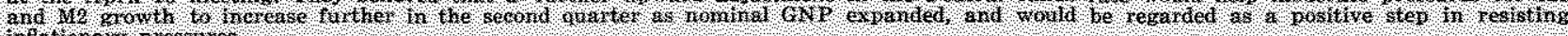

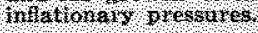

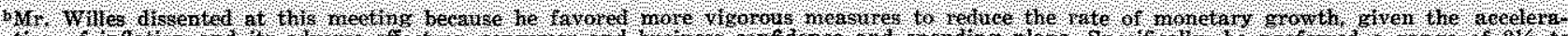

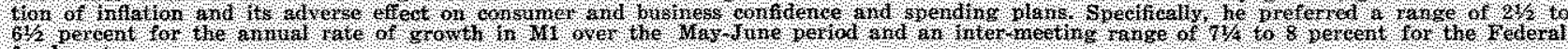

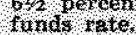

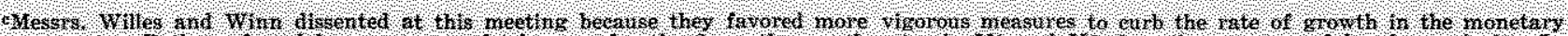

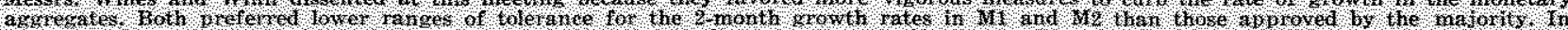

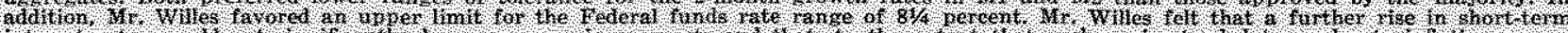

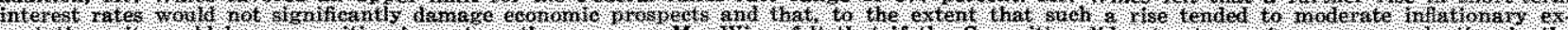

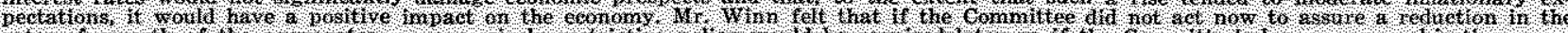

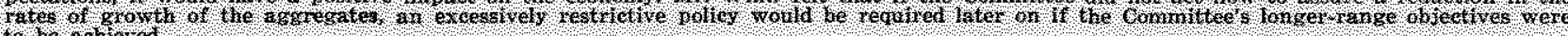
$1010 \mathrm{dneved}$

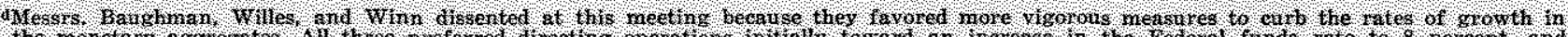

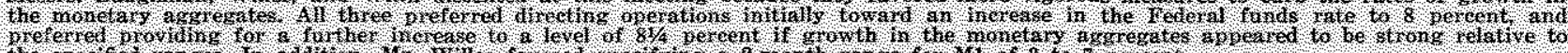

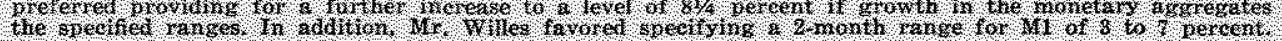

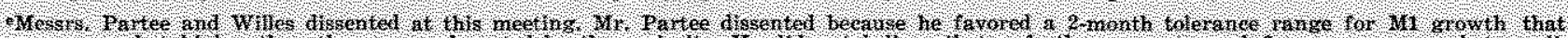

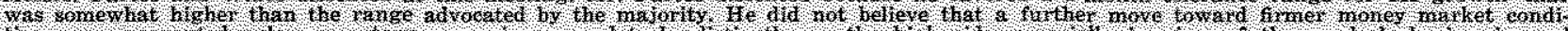

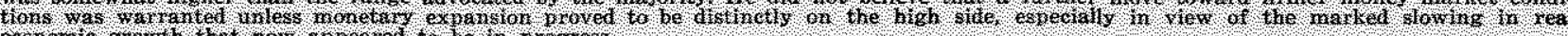

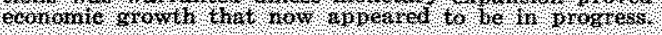

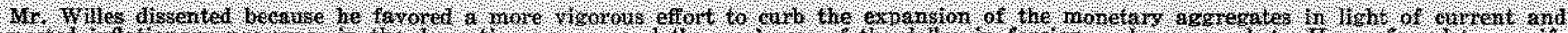

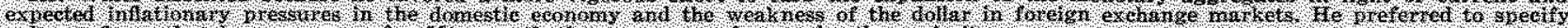

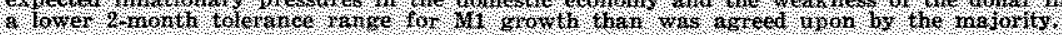

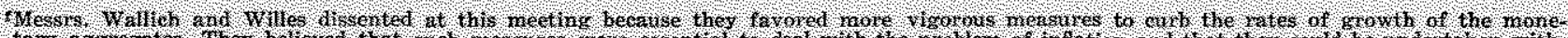

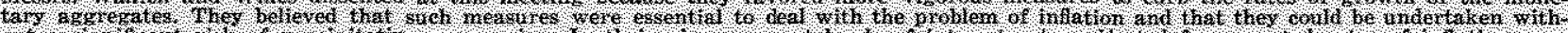

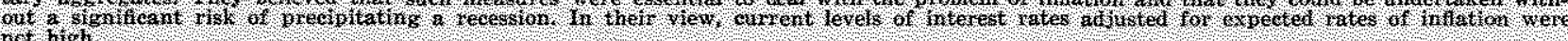
not bill.

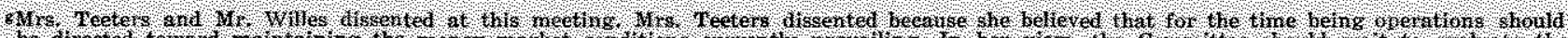

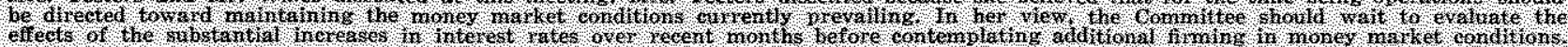

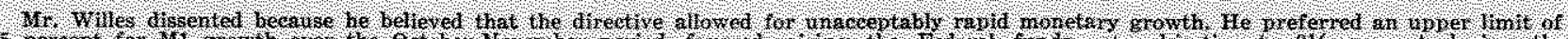

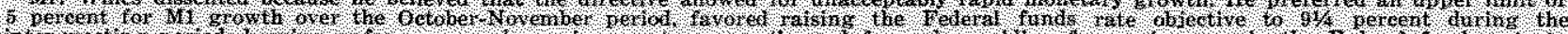

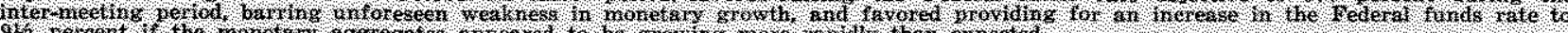

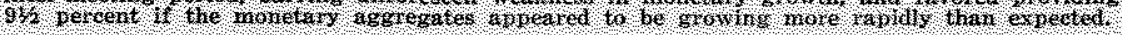

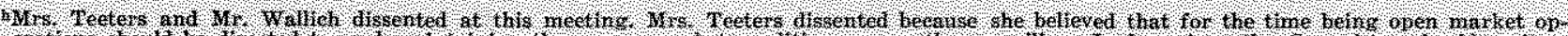

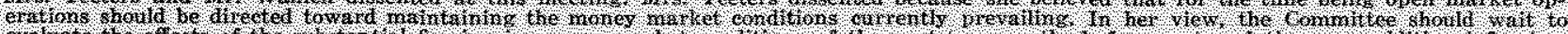

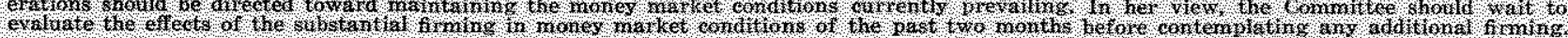

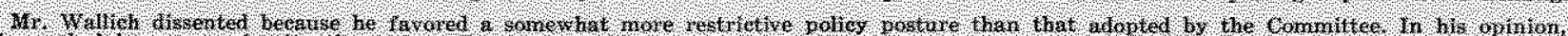

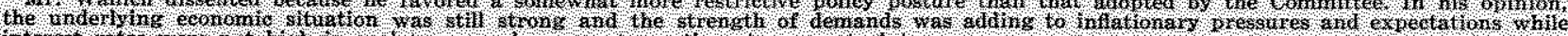

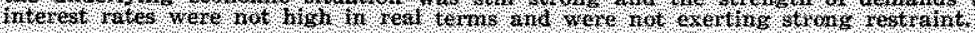

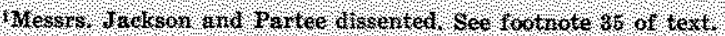

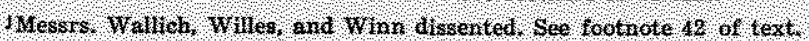

"money market directive," indicated that greater weight was to be given to money market conditions than to growth rates of M1 and M2. In particular, an "aggregates directive" specified that the Federal funds rate objective would be modified within its range if M1 and M2 growth rates appeared to be deviating significantly from the midpoints of their two-month ranges. A "money market directive," on the other hand, specified that the Federal funds rate objective would be modifed within its range if $\mathrm{M} 1$ and $\mathrm{M} 2$ growth rates appeared to be approaching or exceeding the limits of their two-month ranges.

For example, the money market directive of the January 17, 1978 meeting stated:

If, giving approximately equal weight to $M 1$ and M2, it appears that growth rates over the two-month period are approaching or moving beyond the limits of the indicated ranges, the operational objective for the weekly-average Federal funds rate shall be modified in an orderly fashion within a range of $6 \% 2$ to 7 percent. ${ }^{4}$ [Italics added.]

*"Record" (March 1978), p. 207.
In contrast, the aggregates directive of the April 18,1978 meeting stated:

If, giving approximately equal weight to $M 1$ and $M 2$, it appears that growth rates over the two-month period will detiate significantly from the midpoints of the indicated ranges, the operational objective for the Federal funds rate shall be modified in an orderly fashion within a range of $63 / 4$ to $71 / 2$ percent. $^{5}$ [Italics added.]

The wording of the domestic policy directive began to change with the May meeting. In previous directives, the Committee indicated that M1 and M2 growth rates within the short-run ranges were expected to occur. For example, the April directive stated:

The Committee seeks to encourage near-term rates of growth in $\mathrm{M} 1$ and $\mathrm{M} 2$ on a path believed to be reasonably consistent with the longer-run ranges for monetary aggregates cited in the preceding paragraph. Specifically, at present, it expects the annual growth rates over the April May period to be within

5"Record" (June 1978), p. 476. 
ranges of 4 to $8 \frac{1}{2}$ percent for $\mathrm{Ml}$ and $5^{1 / 2}$ to $91 / 2$ percent for $\mathrm{M} 2{ }^{B}$ [Italics added.]

In the May directive the FOMC deleted the word "expects" with regard to the two month ranges of M1 and M2 growth, changing the wording as follows:

The Committee seeks to encourage near-term rates of growth in M1 and M2 on a path believed to be reasonably consistent with the longer-run ranges for monetary aggregates cited in the preceding paragraph. Specifically, at present, the ranges of tolerance for the annual growth rates over the May-June period will be 3 to 8 percent for $\mathrm{M} 1$ and 4 to 9 percent for M2.7 [Italics added.]

The reasons for this change in wording, along with additional changes in the June directive, were reported in the "Record of Policy Actions" of the June 20, 1978 meeting. The Committee felt that their intentions with regard to the short-run ranges had been misinterpreted at times, partly because of the wording of the directive. Consequently, at the May meeting the FOMC "deleted one potentially misleading phrase from the language previously employed, to the effect that the Committee 'expects' the twomonth growth rates to be within the indicated ranges." ${ }^{8}$ The FOMC made this change to make clear that the two-month ranges of M1 and M2 growth rates were not necessarily the growth rates they expected to occur.

The Committee at the June meeting "agreed upon a more thorough revision of the customary language [of the directive], in an effort to reduce the chances of misinterpretation." 9 The main objective of the changes in the directive's wording was to avoid the possible misinterpretation that the two-month growth ranges were the Committee's short-run target ranges; that the Committee would attempt to achieve Ml and M2 growth rates within these two month ranges by changing the Federal funds rate. The Committee noted that the two-month ranges could not be considered targets.

In fact, however, the Manager [of the System Open Market Account] could not be expected regularly to achieve two-month growth rates in $\mathrm{Ml}$ and M2 within the specified ranges for various reasons including the lag between changes in the Federal funds rate and changes in these growth rates, and

Elbid.

7“Record" (July 1978), pp. 564-65.

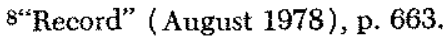

Ilbid. the brevity of the period to which the operational paragraphs of any single directive applied.10

According to the Committee, adjustments in the Federal funds rate are intended to increase the likelihood that the growth rates of M1 and M2 will fall within their one-year ranges.

It was noted in the discussion that the Committee's objectives for the monetary aggregates were embodied in the one-year ranges established at quarterly intervals, and that the adjustments made from time to time in the Federal funds rate were intended to increase the likellhood that the longer-run growth rates would fall within these ranges. ${ }^{11}$

What, then, is the purpose of setting two-month ranges of growth for the monetary aggregates? "The purpose of the two-month ranges was to provide the Manager [of the System Open Market Account] with an indicator for determining when changes in the [Federal] funds rate were appropriate. . . "12 [Italics added.]

Revisions in the wording of the directive resulted in the following "aggregates" and "money market" directives. The "aggregates" directive of the June 20 , 1978 meeting stated:

In the short run, the Committee seeks to achieve bank reserve and money market conditions that are broadly consistent with the longer-run ranges for monetary aggregates cited above, while giving due regard to developing conditions in financial markets more generally. During the period until the next regular meeting, System open market operations shatl be directed initially at attaining a weekly-average Federal funds rate slightly above the current level. Subsequently, operations shall be directed at maintaining the weekly Federal funds rate within the range of $7 \frac{1}{2}$ to 8 percent. In deciding on his specific objective for the Federal funds rate the Manager shall be guided mainly by the relationship befween the latest estimates of annual rates of growth in the June-July period of M1 and $\mathrm{M} 2$ and the following ranges of tolerance: 5 to 10 percent for $\mathrm{Ml}$ and 6 to 10 percent for M2. If, giving approximately equal weight to M1 and $\mathrm{M} 2$, their rates of growth appear to be significantly above or below the midpoints of the indicated ranges, the objective for the funds rate shall be raised or lowered in an orderly fashion within its range. ${ }^{13}$

The "money market" directive of the July 18, 1978 meeting stated:

In the short run, the Committee seeks to achieve bank reserve and money market conditions that are

10 Ibid.

11 lbid.

12 Ibid,

13 Ibid., pp. 664-65. 


\section{Twelve-Month $M_{1}$ Ranges Announced During 1978}

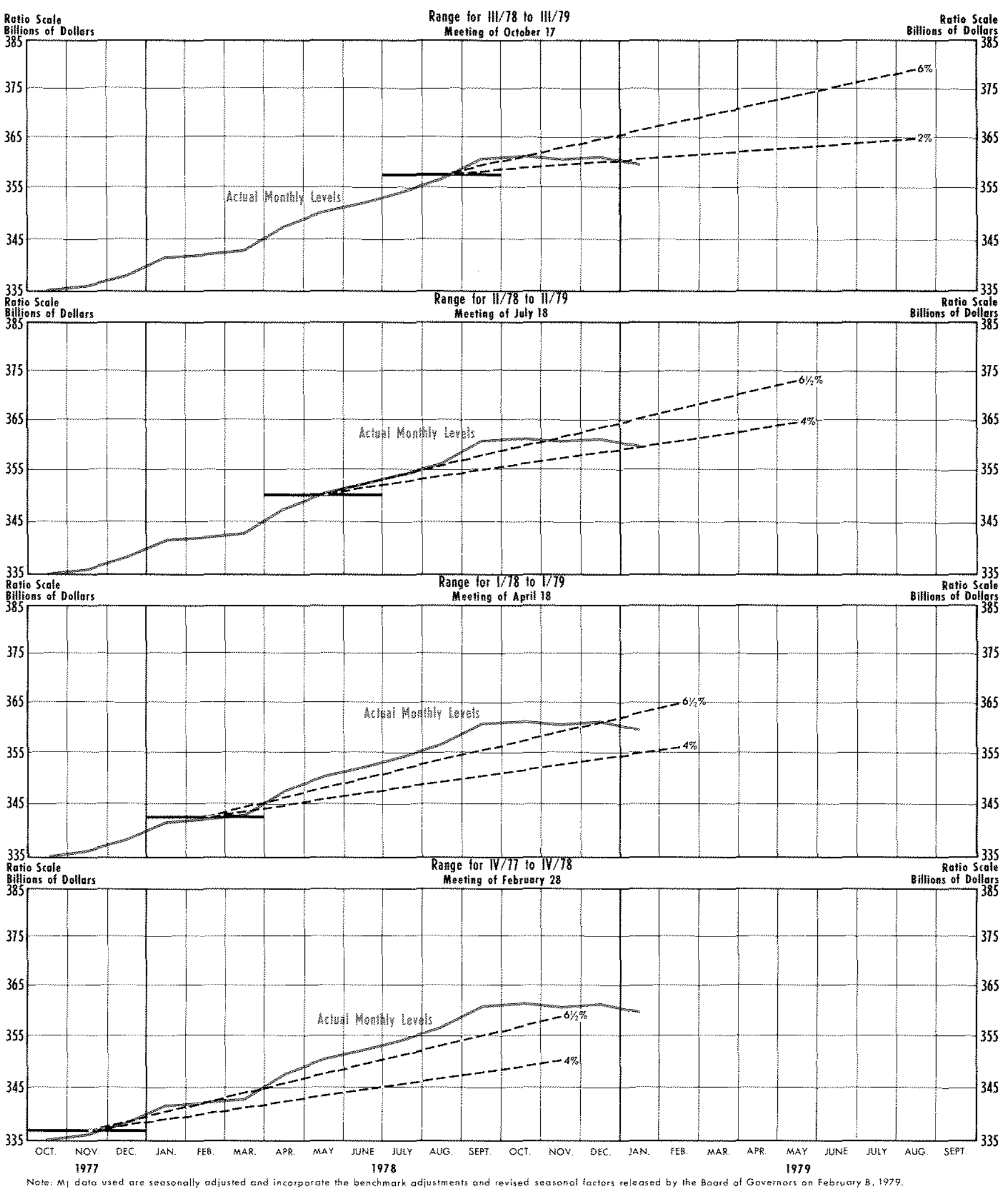


broadly consistent with the longer-run ranges for monetary aggregates cited above, while giving due regard to developing conditions in financial markets more generally. During the period until the next regular meeting, System open market operations shall be directed at maintaining the weekly-average Federal funds rate within the range of $73 / 4$ to 8 percent. In deciding on the specific objective for the Federal funds rate the Manager shall be guided mainly by the relationship between the latest estimates of annual rates of growth in the July-August period of M1 and $M 2$ and the following ranges of tolerance: 4 to 8 percent for M1 and 6 to 10 percent for M2. If, giving approximately equal weight to $\mathrm{M} 1$ and $\mathrm{M} 2$, their rates of growth appear to be close to or beyond the upper or lower limits of the indicated ranges, the objective for the funds rate shall be raised or lowered in an orderly fashion within its range. ${ }^{14}$

The only major difference between these two directives is whether the Federal funds rate objective is to be changed as a result of 1) deviations of monetary aggregate growth from the midpoints of their two-month ranges (an "aggregates directive"), or 2) aggregate growth rates close to or beyond the limits of their two-month ranges (a "money market directive"). These new formats clarify the role that monetary aggregate growth has played in the FOMC's directives, particularly in terms of the weight given to monetary growth relative to money market conditions. The near-term operating objective is the Federal funds rate in either form of the directive, as it had been under the earlier formats.

\section{Short-Run Ranges: Allowing for ATS}

At the October 17, 1978 meeting, the FOMC considered the impact of the introduction of the automatic transfer service (ATS) between checking and savings accounts on their short-run ranges. The Committee noted that the two-month growth rate of $\mathrm{M} 1$ might be reduced significantly as a result of the introduction of ATS, while the two-month growth rate of M2 might be slightly higher than it otherwise would have been. ${ }^{15} \mathrm{~A}$ number of proposals were considered to allow for the effects of ATS on the short-run monetary growth ranges, including one to eliminate $\mathrm{MI}$ as an operating guide entirely. The Committee eventually decided to emphasize the growth of $\mathrm{M} 2$ as a

\footnotetext{
14“Record”' (September 1978), p. 754.

15"Record" (December 1978), pp. 953-54. For a discussion of the effect of ATS on growth of the monetary aggregates, see Scott Winningham, "Automatic Transfers and Monetary Policy," Federal Reserve Bank of Kansas City Economic Review (November 1978), pp. 18-27; or Johm A. Tatom and Richard W. Lang, "Automatic Transfers and the Money Supply Process," this Review (Febrtary 1979), pp. 2-10.
}

short-run operating guide. Only an upper limit for the twomonth growth of M1 was specified, "reflecting a judgment that rapid growth in M1 would have significance for policy while slow growth might represent chiefly transfers from demand to savings accounts because of the introduction of ATS." 16 In the past, M1 and M2 had received roughly equal weight in the Committee's short-run operating instructions.

In light of the uncertainties introduced by ATS, the Committee in October favored giving greater weight than usual to money market conditions. This was also the case at the November 21,1978 meeting, "although some sentiment was expressed for a return to basing decisions for open market operations primarily on the behavior of the monetary aggregates,"17 The Committee in November again placed primary emphasis on M2 growth in specifying its short-run operating ranges, setting only an upper limit on the two-month growth of M1.

The Committee at the December 19, 1978 meeting again specified a lower limit for the two-month range of $\mathrm{Ml}$ growth, and $\mathrm{Ml}$ again was given equal weight with $\mathrm{M} 2$ in assessing the behavior of the aggregates. These changes from the October and November directives were taken "because recent experience had suggested that the impact of ATS on the annual rate of growth of M1 could be estimated within fairly narrow limits." 18

While the October and November directives specified only upper limits for M1 growth because rapid M1 growth was considered more significant than slow M1 growth, the December directive indicated that rapid growth of both $\mathrm{M} 1$ and $\mathrm{M} 2$ were considered more significant than slower growth of M1 and M2. The December directive instructed the Manager of the System Open Market Account to respond more quickly to high rates of M1 and M2 growth than to low rates of growth.

Specifically, the objective for the funds rate was to be raised in an orderly fashion within its range if the two-month growth rates of $\mathrm{M} 1$ and M2 appeared to be significantly above the midpoints of the indicated ranges. On the other hand, the objective was to be lowered in an orderly fashion only if the two-month growth rates appeared to be approaching the lower limits of the indicated ranges. ${ }^{19}$

\footnotetext{
16"Record" (December 1978), p. 954.

17"Record" (January 1979), p. 56.

18"Record" (February 1979), p. 150.

19 Ibid., pp. 150-51.
} 
Twelve-Manth $M_{2}$ Ranges Announced During 1978

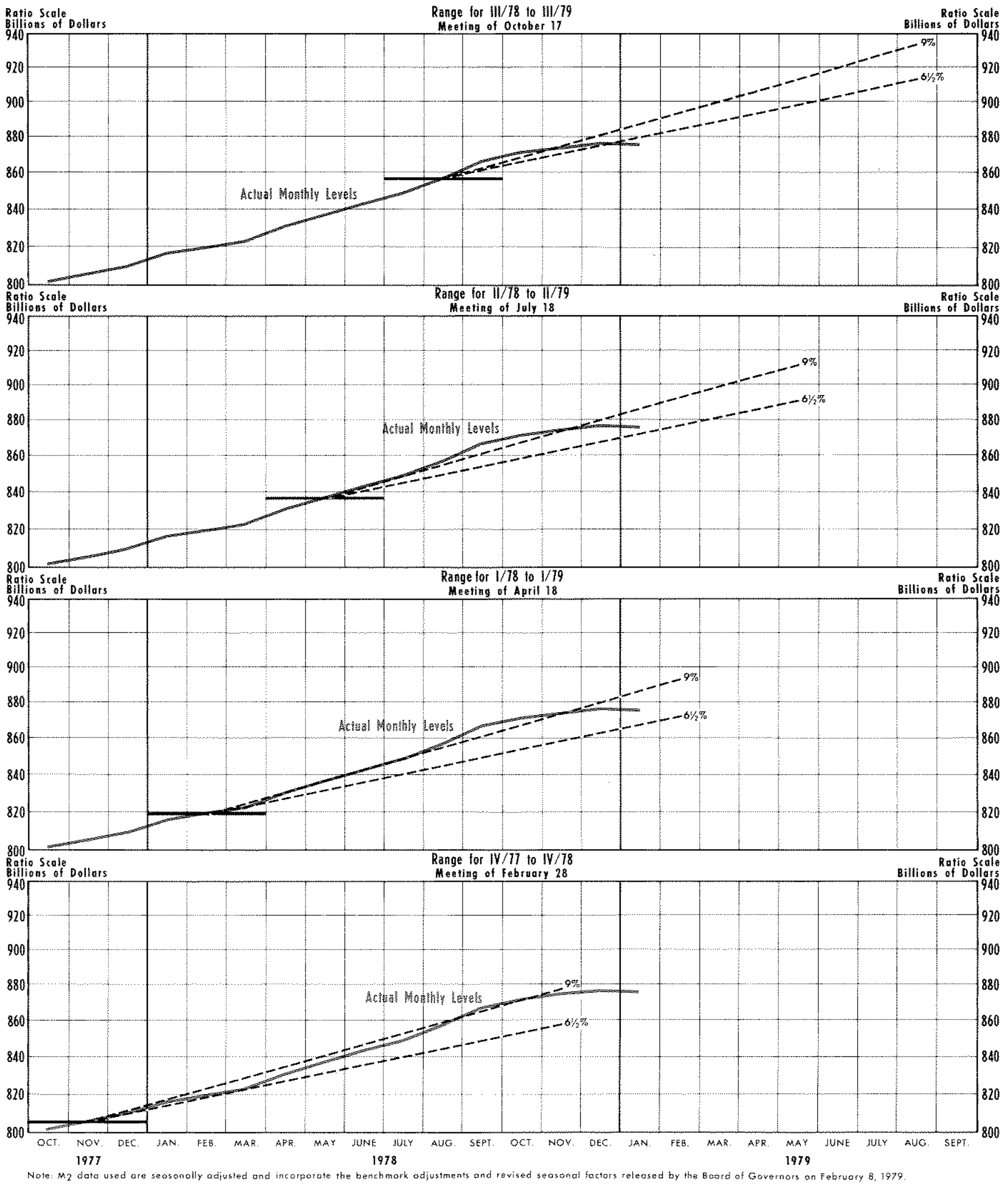


The wording of the December directive indicates that the Committee was no longer as uncertain about the impact of ATS on M1 growth and that, consequently, short-run $\mathrm{M} 1$ growth again could play its role as a guide to changes in the Federal funds rate objective. Thus, the introduction of ATS affected only temporarily the role of M1 in implementing the FOMC's policy directives in 1978.

\section{Show ${ }^{\text {Pun }}$ Ranges: Implementaton}

The Open Market Desk's implementation of the FOMC's domestic policy directives in 1978 resulted in rates of M1 growth that often exceeded the longerrun ranges set by the FOMC (Chart I), and which, at times, exceeded the shorter-run ranges as well (Chart III). Rates of M2 growth, on the other hand, were generally within both the longerrun and shorter-run ranges (Charts II and III). ${ }^{20}$

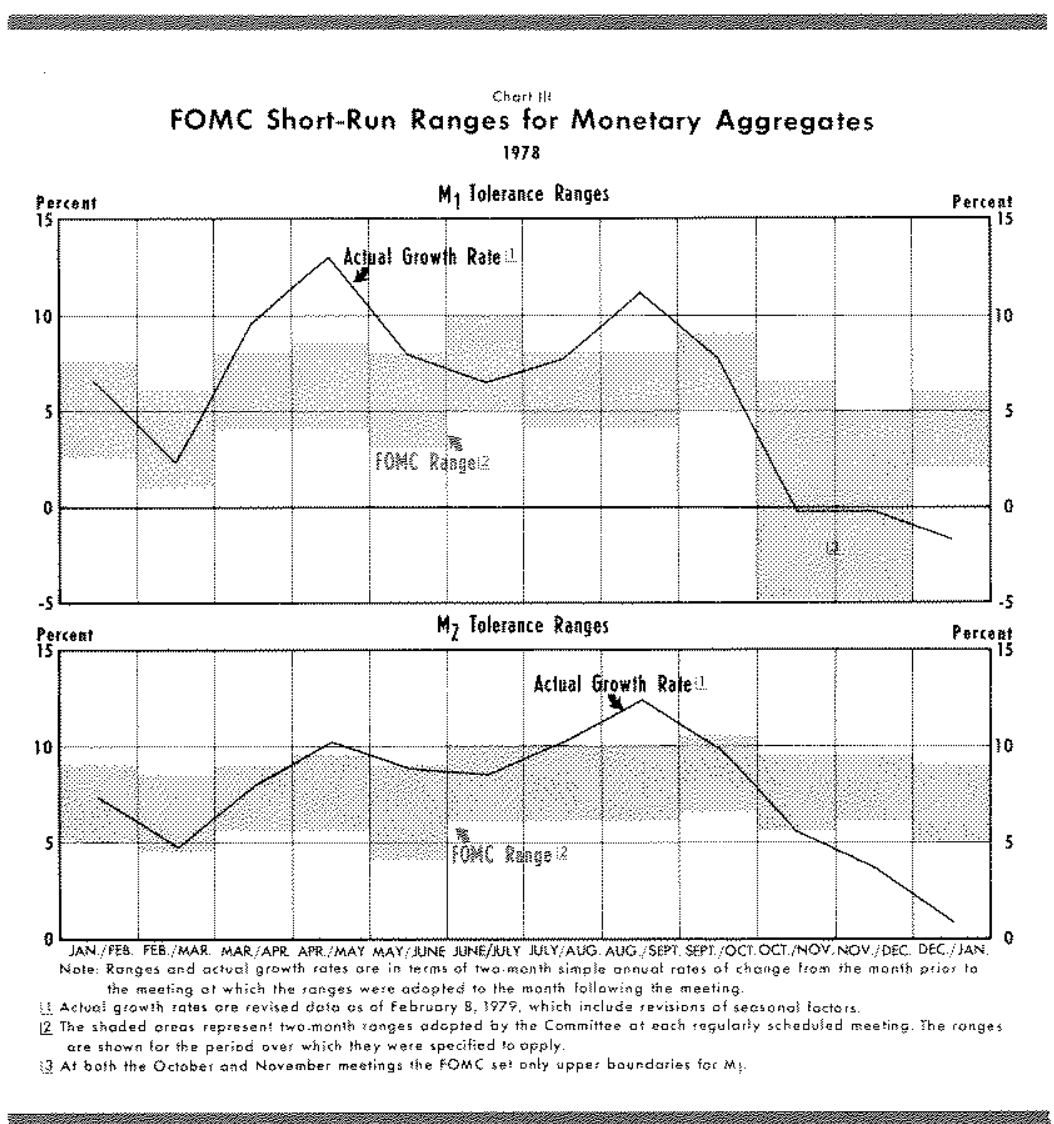

\section{Longer-Tun Ranges}

The FOMC began 1978 with longer-run growth ranges of 4 to $61 / 2$ percent for $\mathrm{M} 1,6 \frac{1 / 2}{2}$ to 9 percent for M2, and 8 to $10^{\frac{1}{2}}$ percent for M3. These ranges, which were adopted in October 1977, applied to monetary growth from third quarter 1977 (III/77) to third quarter 1978 (III/78). The FOMC reviewed these one-year ranges at its February 1978 meeting and decided to reduce both the upper and lower limit of the M3 range by one-half percentage point while leaving the $\mathrm{M} 1$ and $\mathrm{M} 2$ ranges unchanged (Table $\mathrm{I}$ ). When newly-appointed Chairman Miller announced the new M3 range on March 9, 1978, he noted that this reduction was made "in light of the higher level of market interest rates now prevailing and the apparent effect of these rates in retarding growth in time and savings deposits at thrift institutions." 21

The Committee's decision to retain the 4 to $6^{1 / 2}$ percent range for $\mathrm{M} 1$ took into account a number of factors.

First, it was observed that any increase in the $6 \frac{1}{2}$ percent upper limit of the range could strengthen

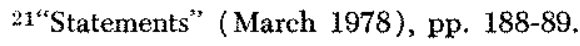

20Data used in the tables and charts are revised data as of February 8, 1979, which include revisions of seasonal factors. Previously-reported data show similar patterns to the data used here, although growth rates differ somewhat. 


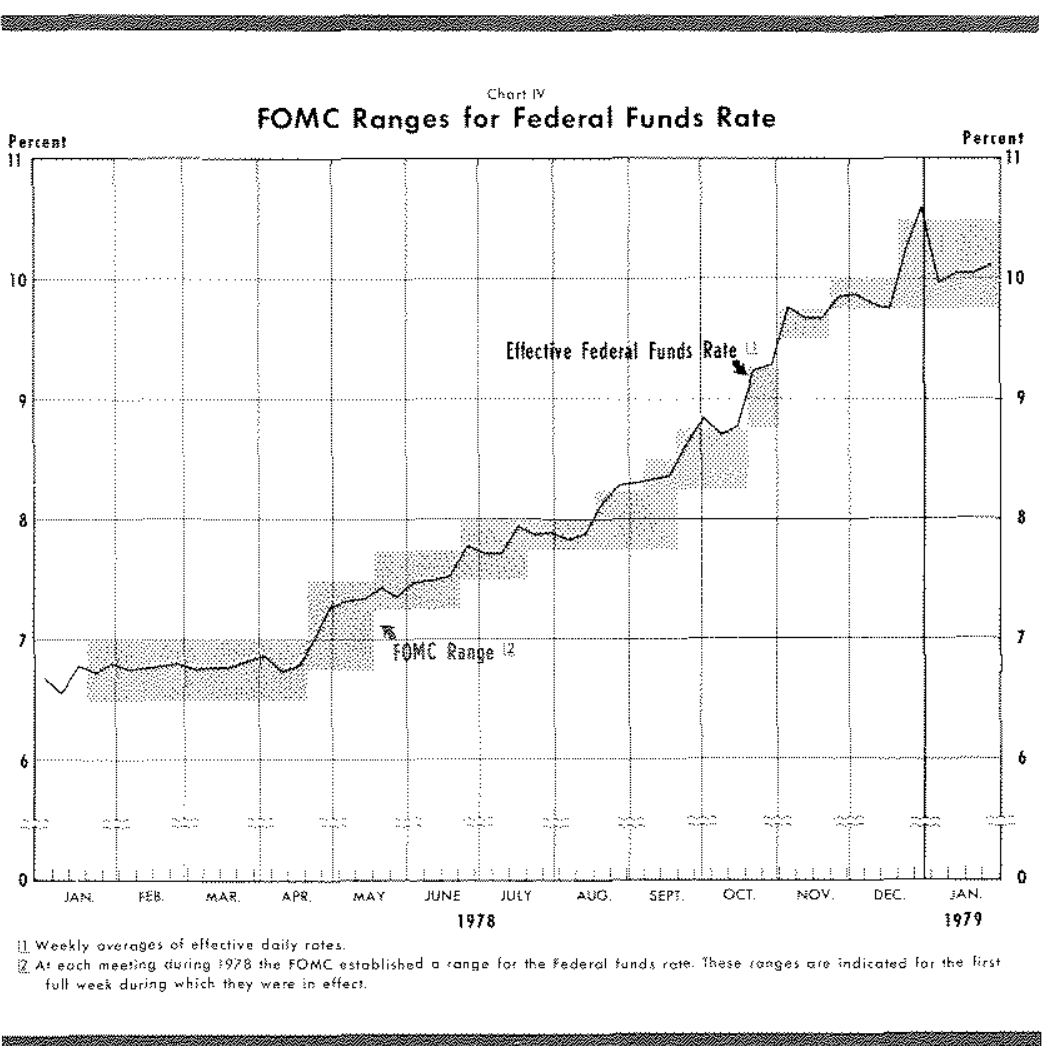

during 1978 from their rates in 1977 . He also emphasized, however, that the Federal Reserve would continue to put "the long-run performance of the economy above the pursuit of any fixed monetary growth rates. ${ }^{{ }_{23}}$

By the April meeting, when the longer-run ranges again were reviewed, the Committee agreed that in the domestic policy directive "more weight should be given to the objective of resisting inflationary pressures. . . ."24 The Committee also remained concerned, as it was during much of 1978 , about the declining value of the dollar in foreign exchange markets. On the basis of data available at the April meeting, M1 growth averaged 5.1 percent over the first quarter of 1978 , declining from the 7.4 percent rate recorded in the fourth quarter of $1977 .^{25}$ Growth of $\mathrm{M} 2$ and M3 also decelerated in the first quarter of 1978 , compared to the fourth quarter of 1977 . Growth rates of all three measures over the first quarter

inflationary expectations, which already appeared to be intensifying, and could accentuate the current weakness of the dollar in foreign exchange markets. Second, because the rate of growth of M1 in 1977 about $71 / 2$ percent - had significantly exceeded the upper limit of the Committee's earlier ranges, it was suggested that a decision now to reduce the range might lack credibility. Third, it was noted that if the actual rate of growth in $\mathrm{M} 1$ during 1978 were to fall within a 4 to $6 \frac{1}{2}$ percent range, that would represent a significant slowing from the 1977 rate. Indeed, one Committee member observed that if - as seemed likely - some slackening were under way in the processes of financial innovation that recently had been facilitating economies in transactions balances, an unchanged rate of growth in M1 could be interpreted as involving an increase in monetary restraint. Finally, it was suggested that current uncertainties regarding the economic outlook militated against an adjustment in the MI range. While Committee members found these considerations persuasive, it was observed in the discussion that further gradual reductions in monetary growth ranges would be needed over time if growth rates consistent with general price stability were to be achieved. $^{22}$

In addition, Chairman Miller noted in his testimony before Congress that the FOMC anticipated that the growth of the monetary aggregates would decelerate

22“"Record”" (April 1978), pp, 297-98. were below the midpoints of their ranges (on the basis of data available in April 1978).

The Committee decided not to change the one-year ranges for $\mathrm{M} 1, \mathrm{M} 2$, and $\mathrm{M} 3$ growth at the April meeting. In announcing these ranges on April 25, 1978, Chairman Miller noted:

Although the FOMC at this time has not made a further reduction in its monetary growth ranges, it remains firmly committed to a gradual reduction in monetary growth over time to rates more nearly consistent with reasonable price stability. The ranges just adopted in fact contemplate that actual monetary growth in 1978 and into early 1979 will be slower than last year. ${ }^{26}$

Several Committee members noted at the April meeting that, since M1 growth had exceeded the $61 / 2$ percent upper limit of its longer-run range in all but one quarter since the fourth quarter of 1976, holding monetary growth within the existing ranges was more important than reducing the ranges further. ${ }^{27}$

23"Statements" (March 1978), p, 189.

24 "Record" (June 1978), p. 473.

süM1 growth for first quarter 1978 was revised up to 6.8 percent in February 1979, while Ml growth for fourth quarter 1977 was revised up to 7.6 percent.

s6 "Statements" (May 1978), p. 376.

${ }_{27}^{4}$ "Record" ( June 1978), p. 471. 
The point was stressed that retention of the existing ranges for the year ahead should be interpreted as constituting a tighter monetary posture than had been contemplated when the ranges were adopted in February 1978. It was observed that since then the prospective rate of inflation had increased - which implied, other things being equal, that nominal GNP and the associated transactions demand for money would expand more rapidly than had been anticipated at that time. It was recognized that such an implication could form the basis of an argument for raising the twelve-month range for $\mathrm{Ml}$, or at least its upper limit. It was suggested, however, that the ultimate conclusion of such an argument was a monem tary policy that always accommodated the existing rate of inflation and that could be expected to lead to still higher rates of inflation and still more rapid monetary growth. 28

It was suggested that the M2 and M3 ranges might be reduced since growth of savings and time deposits at banks and thrift institutions could be expected to slow further as market interest rates rose relative to Regulation $Q$ ceilings. This suggestion received little support, however, and the existing M2 and M3 ranges were retained. ${ }^{29}$

Growth of M1 and M2 accelerated during the second quarter. On the basis of data available at the July meeting, M1 increased at an 8.5 percent rate, well above the upper limit of its longer-run range, and $\mathrm{M} 2$ increased at an 8.5 percent rate, still within its longer-run range. $\mathrm{M} 3$, on the other hand, increased at close to the same rate in the second quarter ( 8.2 percent) as in the first quarter ( 8.0 percent), near the bottom of its range. ${ }^{30}$

The longer-run ranges again were reviewed at the July meeting. Most members of the Committee agreed to retain the existing ranges for $\mathrm{M} 2$ and $\mathrm{M} 3$, but fewer agreed about the range for Ml. Although a majority of the Committee favored retaining the existing $\mathrm{M} 1$ range, a few of the members preferred to increase its upper limit. ${ }^{3.1}$ The argument to increase the upper limit of the M1 range was based on the expectation that M1 growth over the next four quarters would have to exceed the $6 \frac{1 \%}{2}$ percent upper limit in order to avoid the risk of a downturn in economic activity.

That expectation was based on the probable rates of inflation and on the recent behavior of the income

\footnotetext{
28 Ibid., p. 472.

$29 \mathrm{Ibid}_{2}$ pp. 471-72.

30 Data revisions resulfed in the following second-quarter growth rates as of February 8, 1979: 9.6 percent for M1, 8.7 percent for M2, and 8.7 percent for $M 3$.

31"Record" (September 1978), p. 749.
}

velocity of money. In this connection it was emphasized that the high rate of inflation in prospect for the quarters immediately ahead was attributable in part to governmental actions and to some strong forces in the private sector - including the effects of the depreciation of the dollar - that were not likely to be moderated appreciably by the stance of monetary policy. In these circumstances, it was argued, the Committee ought to raise the upper limit of the range for M1 to allow for a growth rate that - given upward cost pressures on prices - was more nearly consistent with the generally anticipated rate of growth in real and nominal GNP for the year ahead and that, consequently, was more likely to be achieved. ${ }^{32}$

Several arguments were made in favor of retaining the 4 to $6 \frac{1 / 2}{2}$ percent range. First, M1 growth in the second quarter of 1978 had substantially exceeded the $6^{1 / 2}$ percent upper limit. Retaining the same range for $\mathrm{M} 1$ over the period $\mathrm{II} / 78$ to $\mathrm{II} / 79$, and using this higher second quarter level of $\mathrm{Ml}$ as a base, allowed M1 growth to be higher than $6 \frac{1 / 2}{2}$ percent over the fivequarter period beginning in $\mathrm{I} / 78$. Second, M1 growth on average had exceeded the Committee's longer-run ranges for more than one year, so that reducing $M 1$ growth to a rate within the existing range would be a move toward moderating inflation. Third, an increase in the M1 growth range could be misinterpreted as a de-emphasis of the FOMC's policy of fighting inflation.

Since that was not the case, it would be consistent to retain the existing range, although the rate of growth over the period might be around the upper limit of the range ${ }^{33}$

A final argument against changing the MI growth range involved the impact of ATS on the growth of M1 after November 1, 1978. Members of the Committee noted that ATS would tend to "reduce the demand for M1 and increase its income velocity," so there could be slower M1 growth over the period II/78 to II/79 without necessarily reducing growth of real output. ${ }^{34}$

Although a majority of the Committee voted in July to retain the existing ranges for $\mathrm{M} 1, \mathrm{M} 2$, and $\mathrm{M} 3$, there were two dissenting votes. ${ }^{35}$ In addition, one member of the Committee proposed that increased emphasis

\footnotetext{
32 lbid., p. 750.

33 Ibid.

${ }^{34}$ Ibid., pp. 750-51.

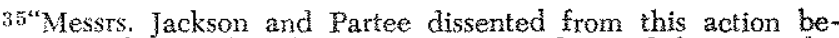
cause they preferred to raise the upper linit of the range for M1 to s level more nearly consistent with the anticipated growth in GNP - Mr. Jackson, to $7 / 2$ percen; Mr. Partee, to 8 percent," bid., i. 751 .
} 
be given to $\mathrm{M} 2$ growth in the future, and reduced emphasis be given to M1 growth. Although this proposal received no support from other Committee members at the time. it was temporarily adopted for both the short and long-run ranges at the October 17, 1978 meeting as a result of the discussion of the possible impact of the introduction of ATS.

Chairman Miller outlined the impact of ATS on the growth of M1 and the broader monetary aggregates on July 2S, 1978, when he announced the longer-run ranges set at the July 18 meeting. He noted that during the transition period in which bank customers adjust to ATS, M1 growth would be lowered while M2 and M3 growth would be little affected. M2 and M3 growth were expected to grow within their ranges, although there "are always great uncertainties surrounding monetary projections." 36

In announcing the longer-run ranges in fuly, Chairman Miller also reported that the FOMC saw little chance that inflation would diminish over the next four quarters, particularly because of certain inflationary biases that exist in the U.S.

These biases - regulatory, legislated, and expectational - prevented the Committee from taking a further step at this time toward the lowering of the monetary growth ranges - a process that must be continued over time if the Nation is to achieve reasonable price stability. ...

These observations underscore the limitations of monetary policy as the main bulwark against inflation and the need to mount a broad attack on the economic problems we face. ${ }^{37}$

During the third quarter, all of the monetary aggregates increased at rates near or above the upper limits of their long-run ranges. At the time of the October 17 meeting when the longer-run ranges again were reviewed, Committee members continued to anticipate moderate growth of real output over the year ahead, although some members felt that the possibility of a downtum in economic activity in 1979 had increased. ${ }^{38}$ The Committee noted that it was faced with two unusual causes of uncertainty in setting the longer-run monetary growth ranges. One was the effect of the ATS program and the other was the form and effect of the President's forthcoming wage and price program.

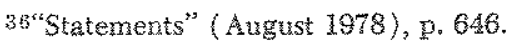

3 This.d.

$35^{* 2}$ Recore" (Decermber 1978), p. 950.
}

The point was made in the Committee's discussion that the wage-price program would have its greatest impact were it not considered a substitute for fiscal and monetary restraint. The effect of the ATS program on growth of the aggregates received further discussion by the Committee, and weighed heavily in their choice of a range for $\mathrm{Ml}$ growth. A staff analysis indicated that ATS would lower MI growth by a signifcant, but uncertain, amount while M2 growth could be raised slightly. M3 growth was not likely to be noticeably affected, according to the staff report. ${ }^{39}$

A number of proposals to deal with the uncertainties raised by the introduction of ATS were discussed. One proposal was to eliminate M1 from the list of monetary aggregates and adopt ranges only for M2 and M3. Another proposal was to adopt M1, M2, and M3 ranges as at previous meetings, in the expectation that the introduction of ATS would have little effect on monetary growth in the few months before the longer-run ranges again were reviewed. Other proposals suggested modifying the $\mathrm{M} 1$ range by changing either the lower limit or both limits to take into account the effect of ATS on M1 growth over the next four quarters. One of these proposals also suggested the consideration of a growth range for an additional monetary aggregate, $\mathrm{Ml}+$ (defined as $\mathrm{Ml}$ plus savings accounts at commercial banks, negotiable orders of withdrawal [NOW] accounts, demand deposits at mutual savings banks, and credit union share drafts).$^{40}$

A majority of the Committee voted to retain the existing ranges for $\mathrm{M} 2$ and M3 (Table I) for the period III/78 to III/79. The Committee also indicated that it expected growth of $\mathrm{M} 1$ to be within a range of 2 to 6 percent over that period, "depending in part on the speed and extent of transfers from demand to savings deposits resulting from the introduction of ATS." 1 This expected range of MI growth was both lower and wider than the one adopted in July. In addition, the Committee noted that a range of 5 to $7^{1 / 2}$ percent for the new monetary aggregate, $\mathrm{M} 1+$, would be generally consistent with the ranges of growth for the other monetary aggregates. Despite the lowering of the $M 1$ range in light of the expected impact of ATS, three of the Committee's members dissented because they felt that an upper limit of 6 percent was too high."2

\footnotetext{
39 ibid., p. 951.

40 bid, p. 952 .

14 bid, p. 953 .

* ${ }^{*}$ Messs. Wallich, Willes, and Wirre dissented from this action because, with the Committees longstanding objective of slow
} 
The wording of the October "Record of Policy Actions" indicated that the Committee placed less emphasis on $\mathrm{M} 1$ relative to $\mathrm{M} 2$ and $\mathrm{M} 3$, because of the uncertainties associated with the introduction of ATS. Whereas the Committee "adopted" ranges of growth for $\mathrm{M} 2$ and $\mathrm{M} 3$ over the period III/78 to III/79, the Committee only "expected" M1 to grow within a range of 2 to 6 percent. ${ }^{43}$ At previous meetings in 1977 and 1978, the Committee had always "adopted" ranges of growth for all three monetary aggregates. ${ }^{44}$ That the M2 and M3 growth ranges were given more weight than M1 by the Committee in October is also evident in Chairman Miller's statement to Congress that "the continuity in the FOMC's objectives with respect to the monetary aggregates for the one-year period from the third quarter of 1978 to the third quarter of 1979 is more clearly indicated by the broader aggregates, M2 and M3."45

In addition, the FOMC at both the October and November meetings placed primary emphasis on M2 growth in specifying its short-run operating objectives, setting only an upper limit on the two-month growth rate of Ml. This change in the domestic policy directive, the change in wording of the longer-run growth ranges, and the widening of the longer-run range of $\mathrm{M} 1$ growth all indicate that the FOMC placed less weight on the behavior of M1 during the latter part of 1978 as a result of the introduction of ATS. However, at the December meeting the Committee returned to specifying a lower limit for the two-month range of $\mathrm{Ml}$ growth, and gave equal weight to M1 and M2 growth. When the longer-run ranges were reviewed at the February 6, 1979 meeting, the Committee again "adopted" growth ranges for all three monetary aggregates. ${ }^{40}$ Thus, the introduction of ATS reduced only temporarily the roles of the M1 growth ranges as guides or objectives of policy.

ing the rate of intation in mind, they preferred to specify an upper limit of less that 6 percent for the rate of growth of M1, adjusted for the estimated effects of ATS. In their view, the upper limit of 6 percent, adjusted for ATS, represented an unwarranted increase from the $6^{\mathrm{L} / 2}$ percent upper limit of the existing (pre-ATS) range." Ibid., pp. $952-53$.

43 Lbid., p. 953 . This distinction was pointed out in comments by the Board staff on an earlier draft of this paper.

44See the "Records" (March 1977), p. 257; (June 1977), p. 571; (September 1977), pp. 832-33; (Decenber 1977), p. 1071: (April 1978), p. 299; (June 1978), p. 473; and (September 1978$)$, p. 751 .

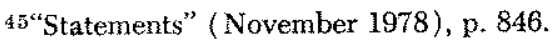

46 "Record of Policy Actions of the FOMC," Federal Reserve Press Release (March 23, 1979), p. 10; forthcoming in the Federal Reserve Bulletin (March 1979).
Nevertheless, Chairman Miller indicated when announcing the monetary aggregate ranges on November 16,1978 that institutional changes such as ATS raise general questions about the use of monetary aggregates in assessing monetary policy.

While monetary aggregates are useful indicators of financial conditions, the continuing change in the institutional environment and in public preferences for different deposits indicates that any single monetary measure, or even a set of several measures, can by no means be the sole focus of policy. Thus, a broad range of financial indicators - including nominal and real interest rates, credit flows, and liquidity conditions - necessarily must be considered in assessing the stance of monetary policy.

... it is clear that in the present environment we cannot rely solely on monetary management to contain inflationary pressures. ${ }^{47}$

He also noted that institutional changes such as ATS can result in existing measures of the monetary aggregates becoming outdated. ${ }^{48}$ Subsequently, the Board of Governors announced a proposal in February of this year to redefine the monetary aggregates, largely in order to take into account recent institutional changes that have increased the variety of deposits available to the public. ${ }^{49}$

\section{SUMMARY AND CONCLUSTONS}

The views expressed by Committee members about both the short- and longer-run ranges of growth of the monetary aggregates and the changes in the domestic policy directive served to clarify and, for a time, to alter the roles of the monetary aggregates in FOMC policy considerations during 1978. The role of the two-month growth ranges for M1 and M2 in adjusting the Federal funds rate objective was clarified at the May and June meetings with changes in the wording of the domestic policy directive. The Committee made it clear that the one-year growth ranges of the monetary aggregates, not the twomonth ranges, embodied the Committee's objectives for growth of the monetary aggregates.

The introduction of ATS in November of last year temporarily shifted the Committee's emphasis away from the narrowly-defined money stock, M1, toward the more broadly-defined aggregates, M2 and M3. The Committee, at the December 1978 meeting, re-

$47^{*}$ "Statements" (November 1978), p. 847,

48 Ibid.

4. A Proposal for Redefining the Monetary Aggregates," Federal Reserve Bulletin (January 1979), pp. 13-42. 
turned to giving $\mathrm{M} 1$ and $\mathrm{M} 2$ equal emphasis in providing guides for determining when to change the Federal funds rate objective, and, at the February 1979 meeting, returned to giving equal weight to M1, $\mathrm{M} 2$, and $\mathrm{M} 3$ in the specification of the one-year growth ranges. An additional monetary aggregate, $\mathrm{M} 1+$, was introduced, but was given less emphasis than $\mathrm{M} 2$ or M3.

Although the Committee in some ways clarified the roles of the various monetary aggregates during 1978 , Chairman Miller's comment in November that current measures of the aggregates "are becoming outdated,"5o and the Board's recent proposal to redefine the monetary aggregates, suggest that the roles of the monetary aggregates in monetary policymaking will be the subject of further debate in 1979. Whether or not additional changes in the roles of the monetary aggregates occur, will depend in large part on the observed effects of ATS on the aggregates during the coming year.

\footnotetext{
50"Statements" (November 1978), p. 847 .
}

\section{SUPPLEMENT}

\section{FOMC Discussions in 1978}

This supplement consists of selected excerpts from the "Record of Policy Actions" for each of the FOMC meetings in 1978. Each "Record" includes analyses of current and projected economic developments, discussions of current policy actions, and long- and shortrun operating instructions issued by the FOMC to the Trading Desk. The full text of each "Record of Policy Actions" appears in issues of the Federal Reserve Bulletin.

\section{Meesting Held on Jonury 17, 1978}

At its December meeting the Committee had decided that operations in the period immediately ahead should be directed toward maintaining about the prevailing money market conditions, provided that the monetary aggregates appeared to be growing at approximately the rates then expected.

The Committee also had included in its directive to the Federal Reserve Bank of New York the following sentence: "In the conduct of day-to-day operations, account shall be taken of emerging financial market conditions, including the unsettled conditions in foreign ex- change markets." This instruction had been added to provide the Manager with somewhat greater flexibility, in part because of the Committee's view that pressures on the dollar in foreign exchange markets might appropriately influence the nature and timing of domestic open market operations from day to day.

On January 4,1978 , it was announced that the Exchange Stabilization Fund of the U.S. Treasury would henceforth be utilized actively, together with the swap network operated by the Federal Reserve System, to check speculation and to help re-establish order in the foreign exchange markets. On January 6 the Board of Governors announced approval of an increase in Federal Reserve discount rates from 6 to $6^{1 / 2}$ percent, and in an accompanying press release noted that the recent disorder in foreign exchange markets constituted a threat to orderly expansion of the domestic and international economy. The Board expressed the hope that the need for this increase would prove temporary. It also noted that the condition of the domestic economy was sound and that credit supplies to sustain the economic expansion would remain ample.

With the monetary aggregates apparently expanding at rates well within the Committee's specified ranges, the Manager of the System Account continued to aim for a 
Federal funds rate of around 6\% percent in the last weeks of December and the first statement week of January. Due to technical factors, however - including the usua money market chuming around year-end - Federal funds actually traded at rates somewhat above this level. The Manager in early January also shaded his Federal funds rate objective slightly upward because of downward pressures on the dollar in foreign exchange markets. On January 9 , following the January 6 increase in Federal Reserve discount rates to $61 / 2$ percent, the Federal Open Market Committee concurred in the Chaiman's recommendation to raise the inter-meeting range for the Federal funds rate to $6 \frac{1 / 2}{2}$ to 7 percent and to instruct the Manager to aim for a rate of around $6^{3 / 4}$ percent over the next few days. In the days remaining until this meeting, the funds rate averaged 6.75 percent.

According to the latest projections, growth in real gross national product (GNP) would be sustained at a good pace throughout 1978. It was also expected that the rise in prices would remain relatively rapid and that the unemployment rate would decline moderately further over the year ahead.

In the Committee's discussion of the economic situation, most members agreed that the staff's projection of the growth rate in real GNP over the full year 1978 was reasonable. However, there was some difference of opinion regarding the probable profle of the expansion during the course of the year. Specifically, a number of members thought that growth might be faster in the first half of 1978 and slower in the second half than had been projected.

Serious concern continued to be expressed about the dollar's weakness in foreign exchange markets. . . . As at the December meeting, the observation was made that the position of the dollar would be strengthened by adoption in this country of an effective energy program, of a tax policy conducive to business investment here, and of a more effective attack on inflation, as well as by pursuit abroad of faster rates of economic growth.

In the Committee's discussion of policy for the period immediately ahead, a number of members suggested that any significant easing of money market conditions would be undesirable at this time because of the weakness of the dollar in foreign exchange markets and - in the view of some - because of the cumulative growth rates in the monetary aggregates over recent months. Each of the three members who had dissented from the decision of January $\theta$ to seek a higher Federal funds rate indicated that he would not now advocate a rollback since that decision had been implemented and absorbed by the financial markets. At the same time, there was little sentiment for further firming actions in the coming inter-meeting period unless the monetary aggregates appeared to be growing at rapid rates.

Consistent with these views, most members expressed a preference for continuing to give greater weight than usual to money market conditions in conducting operations in the period until the next meeting of the Committee. However, a few favored basing operating decisions primarily on the behavior of the monetary aggregates, particularly if growth rates appeared to be higher than desired.

At the conclusion of the discussion the Committee decided that operations in the period immediately ahead should be directed toward maintaining prevaling money market conditions, as represented by the current $6 \% 4$ percent level of the Federal funds rate. . . . It was understood that very strong evidence of weakness in the monetary aggregates would be required before operations were directed toward reducing the Federal funds rate from its current level.

\section{Meeting Feld on February 28,1978}

Data that became available during the inter-meeting period suggested that growth in the monetary aggregates over the January-February period would be well within the specified ranges. The Manager of the System Open Market Account, therefore, continued to aim for a Federal funds ate of around $6 \%$ percent.

Other short-term interest rates also changed little on balance over the inter-meeting period, even though shortterm credit demands remained relatively strong.

The latest projections suggested that growth in output would be less rapid in the frist quarter of 1978 than had been expected earlier, in large part because of the adverse weather, but that the weather-related losses would be about made up later.

In the Committee's discussion of the economic situation and prospects, the members agreed that the expansion in activity was likely to continue throughout 1978. Most members thought that the staff's GNP projection was reasonable, but two or three members believed that growth in real GNP would fall somewhat short of the projected rate. Several members emphasized that the degree of uncertainty with regard to economic prospects and projections had been increasing.

It was observed that at the current stage of this business expansion some deceleration in growth toward a rate that could be sustained for the longer term would be a desirable development. The comment was also made that some deceleration would be acceptable in light of the inflationary pressures in the economy and of recent developments in the foreign exchange markets.

Considerable concern was expressed that the rate of inflation might accelerate significantly as the year progressed. The comment was made that prospects for inflation had been inhibiting business decisions to invest in fixed capital, and it was suggested that an acceleration would adversely affect confidence and would dampen expansion in spending of other kinds. Such price behavior, it was noted, would pose difficult questions concerning the appropriate role of monetary policy.

In the Committee's discussion of policy for the period immediately ahead, it was suggested that recent developments in the foreign exchange markets militated against any marked easing of money market conditions at this time, and that the uncertainties in the economic situation militated against any market firming. All of the mem- 
bers favored directing initial open market operations during the coming inter-meeting period toward the objective of maintaining the Federal funds rate at about the prevailing level of $6 \%$ percent, and a majority preferred to contimue giving greater weight than usual to money market conditions in the conduct of operations until the next meeting.

\section{Meeting Held on March 21, 1978}

As the inter-meeting period progressed, it became evident that in February $M 1$ had contracted somewhat and $\mathrm{M} 2$ had increased relatively little. Staff projections for the February-March period suggested that M1 would grow at a rate below the lower limit of the range specified by the Committee and that $M 2$ would grow at a rate close to its lower limit. It also appeared, however, that the weakness in the aggregates might reflect the prolongation of the coal strike and the severe winter weather and in view of recent developments in foreign exchange markets, the Committee voted on March 10 to instruct the Manager to continue aiming at a Federal funds rate of $6^{3 / 4}$ percent for the time being. For the full inter-meeting period, the funds rate averaged $6 \%$ percent.

The information reviewed at this meeting suggested that growth in real output of goods and services in the first quarter of 1978 had been adversely affected by unustually severe weather and by the lengthy strike in coal mining but that the underlying economic simation had changed little.... Staff projections suggested, however, that the shortfall in growth from the rate expected at the time of the February meeting would be about made up over the next quarter or two and that on the average over the four quarters of 1978 output would grow at a good pace.

The Committee members agreed that the rate of price advance was likely to remain relatively rapid in 1978, and they expressed a great deal of concern about this prospect. The comment was made that the pace of increase in prices appeared to be accelerating in this country while decelerating in European countries. Several members observed that inflation led to recession, and it was suggested that the greater the inflation, the worse the ensuing recession. For that reason, it was suggested, special emphasis should be given to the Committee's long-standing objective of helping to resist inflationary pressures while simultaneously encouraging continued economic expansion. It was noted that an effective program to reduce the rate of inflation had to extend beyond monetary policy.

In the Committee's discussion of policy for the period immediately ahead, it was suggested that an easing of money market conditions would be inappropriate in light of the outlook for prices, the recent behavior of the dollar in foreign exchange markets, and the likelihood that the demand for money would strengthen substantially again as growth of nominal GNP picked up. It was also sug. gested that a firming of money market conditions in the absence of actual evidence of excessive growth of the monetary aggregates would be premature, given the weakness of recent economic statistics, the still unsettled coal strike, and uncertainty about the strength of the prospective rebound in economic activity. However, a number of members favored some firming of money market conditions during the inter-meeting period with a view to keeping under control the anticipated pickup in monetary growth, unless data for the first 2 weeks of the period suggested that monetary growth over the March-April period was likely to be significantly weaker than expected. There was also some sentiment for a slight easing if the incoming data suggested unexpected weakness in monetary growth.

These differences of emphasis notwithstanding, members of the Committee did not differ greatly in their preferences for operating specifications for the period immediately ahead, and all favored a return to basing decisions for open market operations between meeting dates primarily on the behavior of the monetary aggregates.

All of the members favored directing open market operations during the coming inter-meeting period initially toward the objective of maintaining the Federal funds rate at about the prevailing level of $6 \% / 4$ percent.

\section{Meeting Held on April 18, 1978}

Projections made on the basis of data that had become available in the days immediately following the March meeting suggested that over the March-April period both M1 and M2 would grow at rates that were high within their specified ranges. The figures were regarded as especially tentative, however, since the strength was concentrated in the part of the period for which growth rates were projected. Consequently, the Manager of the System Open Market Account contimued to seek a Federal funds rate of about $6 \% / 4$ percent.

Market interest rates in general were subjected to upward pressure during much of the inter-meeting period, apparently because of investor concerns about the deterioration in the balance of U.S. foreign trade, the acceleration of the rise in prices, and the possibility of a surge in monetary growth in April.

The rate of expansion in total credit at U.S. commercial banks during March was close to that in February. Growth in loans, particularly business loans and real estate loans, accelerated. At the same time banks reduced their holdings of Treasury securities - resuming the pattern of net liquidation of investments that had been interrupted by substantial acquisitions of Treasury securities in February. Over the first quarter, total bank credit grew at an annual rate of about $10^{1 / 2}$ percent, compared with $81 / 2$ percent in the second half of 1977 . Business loans (net of bankers acceptances) increased in March at an amual rate of 23 percent, approaching the rapid pace recorded in the first half of 1974

In the Committee's discussion of the economic situation, most members indicated little or no disagreement with the staff projection of moderate growth in real GNP over the year ahead, following the curtent rebound from the slow pace estimated for the first quarter. However, several members expressed the view that growth would be stronger in the current quarter than had been projected. 
Committee members in general were deeply concerned about price prospects. Views were expressed to the effect that people in both the public and private sectors appeared as yet not to be making the sorts of difficult decisions required to reduce the pace of the rise in prices; that expectations of a high rate of inflation seemed to be growing and, as a result, actions of businessmen and consumers might tend to make their expectations self-fulfilling; that the rate of increase in wage rates might well accelerate if prices rose at the projected rate or if the labor contract recently negotiated in the coal industry were viewed as a pattern-setter; and that individual efforts to profit from inflation could lead to some speculative activity. The comment was also made that in the past several weeks the public's attention increasingly had been focused on the problem of inflation.

It was noted that the current rise in prices was more rapid than the rate that had been projected early in 1977 . Questions were raised as to whether the recent acceleration of the rise was attributable primarily to special factors affecting foods and to the depreciation of the dollar in foreign exchange markets or whether it reflected more general influences, such as the pressures that frequently emerge in the latter phase of a business upswing or the effect of the rate of monetary growth during 1977. As at other recent meetings, the observation was made that monetary policy could be no more than one element in an effective program to fight inflation.

In considering the language of the domestic policy directive to be adopted at this meeting, Committee members agreed that in the statement of the Committee's general policy stance in the fourth paragraph more weight should be given to the objective of resisting inflationary pressures by citing that objective first.

In the discussion of policy for the period immediately ahead, members of the Committee took account of the likelihood that the demand for money would expand significantly in association with the current rebound in economic activity and of the early indications that M1 was growing rapidly in April. All of the members agreed that operations designed to achieve firmer market conditions needed to be undertaken promptly if M1 growth were to be held to a path reasonably consistent with the Committee's longer-run range. At the same time the members felt that, pending additional evidence on the pace of monetary expansion, the degree of fiming sought should be modest.

All of the members favored directing open market operations during the coming intermeeting period initially toward a Federal funds rate slightly above the current level of $6 \%$ percent.

Subsequent to the meeting, on May 5, a telephone conference meeting was held ... pursuant to the decision at the April meeting that an increase in the Federal funds rate above $7 / / 4$ percent . . . would not be sought until the Committee had had an opportunity for further consideration.

The acceleration of growth of nominal GNP in the cur rent quarter from the reduced pace in the first quarter appeared to be the main factor explaining the sharp acceleration of monetary growth in April. Other transitory forces - specifically, mobilization of cash by the public to make unusually large payments of Federal income taxes not withheld, somewhat slower processing of tax returns, and the upsurge in the volume of trading on the stock exchanges - might also have contributed to the April rate of monetary growth.

In its discussion the Committee agreed that, while the firming in money market conditions that had been accomplished since the meeting of April 18 had clearly been appropriate, there was some question as to whether further firming at this point would be desirable.

At the conclusion of the discussion the Committee directed the Manager, until further instructed, to seek to maintain the weekly-average Federal funds rate at about $71 / 4$ percent, with any deviations tending to be in the direction of higher rather than lower funds rates.

\section{Meefing Held on May 16, 1978}

The narrowly defined money supply (M1), which had grown at an annual rate of 5 percent in the first quarter on a quarterly-average basis, expanded at a rate of 19 percent in April. . . . The latest weekly data suggested that growth of MI would slow substantially in May.

The rate of expansion in total bank credit accelerated sharply in April, reflecting an unusually large increase in security loans and sizable additions to bank holdings of both U.S. Government and other securities.

The rise in the Federal funds rate was accompanied by upward pressures on interest rates in general.

In the Committee's discussion of the economic situation and outlook, the members generally agreed that real output of goods and services was growing rapidly in the current quarter, but they differed on the likely course of activity in succeeding quarters.

Committee members were deeply concerned about the recent acceleration of inflation and about prospects for prices. Several expressed the view that the rise was likely to be more rapid than projected by the staff. Thus, it was suggested that the supply-related increase in prices of foods over the remainder of 1978 would exceed the staff projection and that the effect on the over-all price level this year would infuence the outcome of labor contract negotiations in 1979 . It was also suggested that pressures had begun to develop on labor resources, particularly skilled labor, and on some types of capacity. A few members observed that in these circumstances it would be desirable for growth in real output to diminish in the second half of this year toward a rate that could be sus. tained for the longer term.

Committee members differed somewhat in their judgments conceming the course of policy for the period immediately ahead, in part because of varying views about the current and prospective economic situation and in 
part because of differing judgments about the appropriate response to the surge of $M 1$ in April. The differences essentially concemed the degree of any further firming of money market conditions that might be pursued during the next few weeks. No member advocated an easing of money market conditions.

Several reasons were advanced for pursuing a very cautious approach to any further firming at this time, including the fact that transitory influences had contributed to the April surge in Ml. It was observed that, despite the surge, the annual rate of growth of $\mathrm{Ml}$, and also of M2, over the 3,6, and 12 months ending in April had been lower than growth over the four quarters of 1977 . It was also noted that a significant degree of firming of money market conditions had been achieved since the April meeting of the Committee. Moreover, it was pointed out, the administration's new tax proposals - which had just been announced - were considerably less stimulative than the earlier ones, particularly as they affected the fourth quarter of 1978. It was suggested that further significant monetary firming at this time might risk provoking dislocations in financial markets that would contribute eventually to the onset of a downturn in economic activity. Finally, it was argued, a very cautious approach would give the Committee time to evaluate incoming evidence concerning both the underlying strength of economic activity and the consequences of the firming that had already been achieved.

In support of a somewhat more restrictive posture, it was suggested that the relatively low rate of growth of M1 in the first quarter of 1978 represented an aberration related to the temporary weakening in the pace of economic activity and that, abstracting from that aberration, the trend of monetary expansion had accelerated. Views were expressed to the effect that further significant firm. ing of money market conditions in the coming period in order to moderate growth of the monetary aggregates would have a beneficial effect on public confidence; that partly for that reason, such firming would reduce the chances for a further buildmup of inflationary forces, and that it would increase the chances of achieving a rate of growth in real output that could be sustained for the longer term. In this connection, it was suggested that at times in the past when high levels of resource use had been approached, lags in the application of monetary restraint had contributed to bringing on a downturn in economic activity and to increasing the depth and duration of the downturn. The comment was made that if further significant action were not taken in the present circumstances, current monetary policy might be found in rerospect to have been procyclical.

With respect to operating specifications for the period ahead, most members preferred ranges of tolerance for the annual rate of growth in M1 over the May-June period that more or less encompassed the Committee's longer-run range of 4 to $61 / 2$ percent; the preferences centered on 3 to 8 percent.

All of the members favored directing operations during the coming inter-meeting period initially toward a Federal funds rate slightly above the current rate, which was in the area of $71 / 4$ to $7 \frac{3}{8}$ percent.

\section{Meeting Held on June 20, 1978}

Data that became available a few days before this meeting suggested that Ml would grow in the May-June period at an amual rate of about $71 / 2$ percent, close to the upper limit of its range. M2 also was projected to grow in the 2-month period at a $7 / 2$ percent rate, in the upper half of the range specified for that aggregate. These data suggested the need for Committee consultation, and on June 16 , in view of the proximity of the meeting scheduled for June 20 , the Committee voted to direct the Manager to continue for the time being to aim for a Federal funds rate of $7 \frac{1 / 2}{\text { percent. }}$

Other market interest rates had risen further in recent weeks. Reflecting not only the rise in the funds rate but also substantial business credit demands, market rates on short-term securities had increased from 30 to 60 basis points since mid-May, and commercial banks had raised the rate on loans to prime business borrowers in two steps from $8 \%$ to $8^{3} / 4$ percent. Yields on long-term securities rose 5 to 20 basis points over the same period, apparently in response to the rise in short-term rates and investor concems about the prospects for inflation.

The rate of expansion in total bank credit, which had accelerated sharply in April, slackened somewhat in May but remained above the average for other recent months. Bank holdings of securities changed little, but total loans, led by a surge in business loans, grew at an exceptional pace.

The information reviewed at this meeting suggested that output of goods and services had expanded rapidly on the average in the second quarter, reflecting the economy's rebound in late winter and early spring from the effects of the unusually severe winter weather and the lengthy coal strike. More recently, however, the rate of expansion appeared to have slowed. The rise in average prices as measured by the fixed-weighted price index for gross domestic business product - accelerated markedly in the second quarter, due in large measure to substantial increases in food prices.

The renewed downward pressure on the dollar appeared to reflect market concern about the high rate of inflation in the United States relative to rates in other industrial countries and about the continuation of large deficits in U.S. foreign trade and surpluses in the trade of Germany and Japan.

In the Committee's discussion of the economic situation and outlook, the members generally agreed that the growth in real output of goods and services over the coming three quarters would be substantially slower on the average than it had been in the unusually strong quarter just ending. However, they still expected real GNP to grow at a moderate, average rate during the year ending with the second quarter of $1979 .$. . A majority feared that the rise in prices would be greater than the staff anticipated. Most members thought that the unemployment rate at the end of the period would be little changed from the rates recently prevailing.

At this meeting, in discussing policy for the period immediately ahead, Committee members expressed consid- 
erable concern about recent rates of growth in the monetary aggregates, particularly in light of the continuing strength of inflationary pressures and expectations. The members agreed that open market operations in the intermeeting period should be directed initially toward achieving slightly firmer money market conditions, and that later in the period the objectives of operations should depend on incoming data for $\mathrm{Ml}$ and $\mathrm{M} 2$.

There was greater diversity of views with respect to the ranges of tolerance to be specified for the annual rates of growth in $\mathrm{M} 1$ and $\mathrm{M} 2$ in the June-July period. . . It was noted during the discussion that if the monetary aggregates accelerated in June, as suggested by early data, growth over the June-July period at rates near the mid. points of some of the lower ranges proposed could be achieved only if there were to be a sharp slowing in July. Some members, who were inclined to stress the risks to the economy of rapid firming of money narket conditions, saw this circumstance as an argument for specifying relatively high 2 -month ranges for $M 1$ and $M 2$. Other members, who placed more stress on the importance at this time of limiting growth in the aggregates for the sake of moderating inflationary pressures and expectations, thought such firming would be called for if the growth in the aggregates did not in fact slow sharply.

\section{Meeting Feld on Inly 18, 1978}

Incoming data throughout the inter-meeting period sugm gested that growth in the monetary aggregates would be well within the ranges that had been specified by the Committee, and the Manager continted to seek reserve conditions consistent with a Federal funds rate averaging about $73 / 4$ percent. In the final days of the period the funds rate fluctuated around a level somewhat above $7^{3 / 4}$ percent.

The expansion in total credit at U.S. commerical banks slowed substantially in June from the umusually rapid rates in the preceding 2 months, as growth of business loans decelerated sharply after a surge in May. Growth of other types of loans moderated as well, but bank holdings of Treasury securities increased.

Despite the consensus that continuing moderate growth in real GNP was still the most likely development, some members suggested that for a number of reasons - including the high rate of inflation and developing financial stringencies - the probabilities of such an outcome were lower than they had seemed to be earlier. A few members observed that the chances of a decme in output during the period had increased.

All nembers of the Committee expected a continuation of a rapid rate of inflation over the period to the second quarter of 1979 - in the view of several thembers, even more rapid than the pace projected by the staff.

Most members of the Committee thought that the mu employment rate a year ahead, in the second quarter of 1979 , would be litue changed from the average rate in recent months, whoh was well below the level that had been expected carler. It was suggested that the rate of participation in the labor force would continue to rise, in part because of the pressure of inflation on family budgets.

Several members proposed that for the time being operations be directed toward maintaining the money marm ket conditions currently prevailing. It was argued that, in light of increased uncertainties in the economic outlook, such a "patse" would afford the Committee an opportunity to evaluate additional evidence on the current situation and outlook. It was suggested that, coming on top of the considerable firming in money market conditions over the past year or so, further significant firming would risk bringing on a recession. It was also observed that the restraining effects of the rise in interest rates over the past month had not yet been fully felt and that any additional firming that might be appropriate could be achieved at a later time.

On the other hand, a number of members favored a prompt further firming of money market conditions. Such a course was needed, it was suggested, to bring growth in M1 within the Committee's longer-run range. Given the rate of inflation, it was argued, current levels of interest rates were relatively low and were much less restrictive in real terms than their nominal levels might suggest. And the point was made that failure to pursue additional frrming at this time might well create a need for a greater degree of firming later.

With respect to the Federal funds rate, most members favored ranges centered either on $73 / 4$ percent, the midpoint of the $7 \frac{1 / 2}{2}$ to 8 percent range specified at the June meeting, or on the somewhat higher level that had developed in the most recent days; . . A majority of the members favored giving greater weight than insual to money market conditions in the conduct of open market operations until the next meeting.

\section{Meeting Held on August 15, 1978}

In the Committee's discussion of the economic situation, there was general agreement that the outlook for economic activity had changed little since the July meeting, and that in the year ending with the second quarter of 1979 output of goods and services was most likely to grow at about the moderate pace projected by the staft. This judgment was qualified by the recognition that the weakness of the dollar in foreign exchange markets might have unfavorable repercussions on the domestic economy.

Commitee members who differed with the stafir economic protection all expected average growth to be a litte less than the staff fgure.

One negative element in this pattern, which seriously concened all members of the Commitee, was the unexpectedly high recent rate of inlation in prices and wages and the related possibility that an appreciable slowing of inflation would prove more difficult to achieve than pre viously had been anticipated. It was observed in this connection that the declining value of the dollar in foreign exchange markets was contributing significanty to inflation in the United States. Nearly all the Committee members expected price increases for the year ahead to be more rapid than the staft was projecting. 
Other members of the Committee suggested that an important change in the outlook since the July meeting was an apparent stiffening in the resolve of labor leaders to hold out in forthcoming contract negotiations for sizable wage settlements. One member also cited apparent efforts by some businessmen to accelerate increases in wages and prices because of their concern that controls might be imposed.

In the discussion of policy for the period immediately ahead, most members expressed a preference for some slight firming of money market conditions. Several members emphasized the need to restrain the expansion of the monetary aggregates, especially in light of current and prospective inflationary pressures. It was suggested that an indication at this time of the System's continued determination to resist inflation would have a favorable impact on confidence, both in the domestic economy and in foreign exchange markets. With regard to the latter, the members were seriously concemed about the weakness of the dollar. They recognized that interrelated governmental actions would be needed to make progress in this area.

No sentiment was expressed at this meeting for an easing of money market conditions. On the other hand, it was suggested that a sharp move toward restraint under present circumstances might incur an undue risk of precipitating a recession.

There were only small differences among most Committee members in their preferences for operating specifications for the period immediately ahead. They were nearly unanimous in favoring a return to basing decisions for open market operations between meetings primarily on the behavior of the monetary aggregates.

The Committee decided to include in its directive a reference to developments in foreign exchange markets as well as the ustal reference to conditions in the domestic financial markets. The purpose of the added instruction was to provide the Manager with some flexibility to adjust the nature and timing of his operations in light of possible pressures on the dollar in foreign exchange markets.

\section{Meeting Meld on September 10, 1978}

Immediately following the August 15 meeting the Manager of the System Open Market Account began to seek bank reserve conditions consistent with an increase in the weekly-average Federal funds rate to around 8 percent. Later in August, incoming data suggested that growth in M1 would be at the upper limit of the range specifed by the Committee and that growth in M2 would be close to the upper limit of its range. Accordingly, the Manager sought reserve conditions consistent with a firther increase in the Federal funds rate to $81 / 4$ percent, the upper limit of the $73 / 4$ to $81 / 4$ percent range specified for the inter-meeting period.

In early September, avallable data suggested that both M1 and M2 would grow at rates signifcandy above he upper limits of their respective ranges. With the Federal finds rate alrealy at its upper limit, the Commitee decided on September 8 , at telephone conference neeting, to raise the upper limit of the range for the Federal funds rate to $8 \frac{1}{2}$ percent and to instruct the Manager to aim promptly for a weekly-average Federal funds rate of about $8 \%$ percent.

The rise in the Federal funds rate during the inter. meeting period was accompanied by appreciable increases in rates on other short-term market instruments, Yields on long-term securities, however, generally edged down.

After a surge in July, total credit at U.S. commercial banks expanded at a substantially slower rate in August, mainly because of large declines in bank holdings of U.S. Treasury securities and in security loans. Growth in business loans accelerated further but remained well below the average rate in the first half of 1978 .

In the Committee's discussion of the economic situation and outlook, the members generally concurred with the staff's view that real output of goods and services would grow at a moderate pace over the period from the second quarter of 1978 to the second quarter of 1979. At the same time, a number of members anticipated a little less growth than the staff projected and one anticipated a little more. The observation was made that even a slight shortfall in growth of output from the rate projected by the staff implied an upward drift in the unemployment rate.

All members of the Committee expected a continuation of a rapid rate of inflation over the period to the second quarter of 1979 - in the view of several members, even more rapid than the pace projected by the staff.

In the discussion of policy for the period immediately ahead, considerable concern was expressed about recent rates of monetary growth. It was observed that for an extended period of time MI had been growing at rates in excess of the longer-run range adopted by the Committee and that a slowing of growth was necessary in pursuit of the Committee's objective of resisting inflationary pressures while encouraging continued moderate economic expansion. Most members believed that some additional firming in money market conditions during the next few weeks was needed to help assure a slowing in growth of money over the months ahead, although they differed with respect to the degree of fiming that they thought the Committee ought to contemplate.

In this connection, the comment was made that current levels of interest rates were not exerting as much restraint on credit flows as might be supposed. Thus, it was observed, interest rates adyusted for expected rates of inflation were not high and might even be negative. Moreover, the degree of nonprice rationing of credit, particularly credit for housing, had been reduced by such structural changes in the financial system as the introduction of the 6 -month money market certificates.

Two members, stressing the magnitude of the increases in interest rates that had already occurred, proposed that for the time being operations be directed toward maintaining the money market conditions currently prevaling. It was argued that, in hight of the reent slowing of the expansion in economic activity and of uncertainties in the economic outlook, such a "pause" would afford the Com- 
mittee an opportunity to evaluate additional evidence on the current situation, including the effects of the recent increases in interest rates. It was observed that, historically, growth in output had never been held at about its trend rate for very long and that further increases in interest rates at this time might slow growth to a rate below trend or might even provoke an actual downturn.

Most of the members favored directing open market operations toward an increase in the Federal funds rate to about $81 / 2$ percent shortly after this meeting.

\section{Meentivg Hell on October 17,1978}

Following the September 19 meeting the Manager of the System Open Market Account began to seek bank reserve conditions consistent with an increase in the weeklyaverage Federal funds rate to around $81 / 2$ percent. As September progressed, incoming data suggested that growth in MI would be around the upper limit of the range specified by the Committee and that growth in M2 would be in the upper portion of its range. Accordingly, the Manager sought reserve conditions consistent with further increases in the Federal funds rate, and by late September the rate was around $8^{3} / 4$ percent, the upper limit of the inter-meeting range specified by the Committee. During the first half of October the objective for the funds rate remained $83 / 4$ percent, although on many days the rate was above or below that level for technical reasons.

A considerable rise in interest rates on most short-term market instruments was associated with the increase in the Federal funds rate during the inter-meeting period.

The expansion in total credit at U.S. commercial banks, which had slowed in August, accelerated in September nearly to the pace experienced on the average in earlier months of the year.

The Board of Governors announced an increase in Federal Reserve Bank discount rates from $7 \% / 4$ to 8 percent on September 22 and a further increase to $8 \frac{1}{2}$ percent on October 13. Both actions were taken primarily to bring the discount rate into closer alignment with other shortterm interest rates, but also in recognition of conditions affecting the dollar in foreign exchange markets. The Board indicated in addition that the increase of $1 / 2$ percentage point in mid-October was approved in light of the continued high rate of inflation and the recent rapid expansion of the monetary aggregates.

In the Committee's discussion of the economic situation and outlook, the members generally agreed that real output of goods and services was likely to grow moderately over the year ending in the third quarter of 1979, at a rate about or a little below that projected by the staff. ... All members expected that average prices of goods and services would continue to rise rapidly.

Despite the general agreement that real output was likely to grow moderately over the next four quarters, some members cited elements in the current situation that could contribute to a downturn in activity before the end of the period.
In the discussion of policy for the period immediately ahead, nembers of the Committee noted that the uncertainties associated with introduction of ATS would affect growth of the monetary aggregates in the OctoberNovember period - the 2-month period for which growth ranges were being considered - in much the same way as they would growth over the year ahead. Specifically, growth of M1 over the 2-month period might well be less than otherwise by a significant but undetermined amount, and growth of M2 might be marginally greater.

As in the case of the longer-run ranges, various proposals were advanced for taking account of the unusual uncertainties. In general, these proposals involved plac. ing less emphasis on the behavior of $\mathrm{M} 1$ as a guide to operations in the inter-meeting period and more on the behavior of $\mathrm{M} 2$, rather than the approximately equal weight that typically had been given to the two aggregates. . . At the same time, most members of the Committee favored giving greater weight than usual to money market conditions in the conduct of operations in the period until the next meeting of the Committee.

In the discussion, concern was expressed about recent rates of monetary growth, and most members believed that some additional firming in money market conditions in the period immediately ahead was needed to help assure a slowing in growth over the months ahead.

Other members believed that for the time being operations should be directed toward maintaining the money market conditions currently prevailing, as represented by a Federal funds rate of about $87 / 8$ percent, because they felt that such a pause was needed to evaluate the lagged impact of the substantial increases in interest rates over recent months.

Subsequent to the meeting, on October $3 I$, the Committee voted to approve a delegation of authority to Chaiman Miller to take certain actions in implementation of a broad Government program to strengthen the dollar in foreign exchange markets and thereby to counter contimuing domestic inflationary pressures, if he determined that the arrangements with the U.S. Treasury and with certain foreign monetary authorities were substantially as contemplated in a consultation among the members of the Committee on the preceding day.

Early on the morning of November 1 the Treasury and the Federal Reserve announced measures being taken to implement such a program. Specifically, the Board of Governors approved (1) an increase of 1 percentage point, from $81 / 2$ to $91 / 2$ percent, in the discount rate at the Federal Reserve Bank of New York, effective immediately, and (2) establishment of a supplementary reserve requirement, in addition to the existing reserve requirements on deposits at member banks, equal to 2 percent of time deposits in denominations of $\$ 100,000$ or more. At the same time the System announced increases in its reciprocal currency (swap) arrangements with the central banks of Germany, Japan, and Switzerland by a total of $\$ 7.6$ billion, to $\$ 15$ billion, and activation of the swap arrangement with the Bank of Japan. It further stated that the foreign currencies avalable under the expanded arrangements would be used along with foreign currencies avalable to the Treasury in a program of forceful inter- 
vention in the exchange markets in coordination with foreign central banks to correct recent excessive movements in exchange rates.

As part of this program, on October 31 the Federal Open Market Committee voted to approve a delegation of authority to Chairman Miller to modify the domestic policy directive by raising the range for the Federal funds rate to $9 \frac{1 / 2}{2}$ to $93 / 4$ percent and by instructing the Manager, in deciding on the specific objective for the rate within that range, to be guided by developing conditions in domestic and international financial markets. The Chaiman approved the modification of the directive on November I, effective on that date.

\section{Meeting neld on November 21, 1978}

The rise in the Federal funds rate during the intermeeting period was accompanied by substantial increases in yields on most short-term market instruments. Advances in rates on Treasury bills were moderated, however, by large investments by foreign central banks of dollars obtained in currency support operations. Commercial banks increased the rate on loans to prime business borrowers from 10 percent to 11 percent during the period. Yields in bond markets advanced considerably during the second half of October, but a large portion of the increase was offset by sizable declines in early November.

In the Committee's discussion of the economic situation and outlook, most members indicated that over the past month they had scaled down their expected rates of growth in real output of goods and services for the year ending in the third quarter of 1979. One or two members still anticipated moderate expansion over the period, but many projected slow growth, and some thought that a downturn in activity was likely or that the risks of an actual recession or a growth recession had increased. It was emphasized, however, that the uncertainties associated with any forecast of real output had increased significantly.

Most members expected that, over the year ending in the third quarter of 1979 , the unemployment rate either would change little or would increase from the average level in the third quarter of 1978. All members continued to anticipate a rapid rise in average prices of goods and services.

Some skepticism was expressed, as it had been at the October meeting, that growth in output could be tapered down to a relatively slow rate without bringing on a recession, especially in view of the rapid inflation. It was stressed, on the other hand, that economic conditions in this period differed from those in other business expansions in ways that made it reasonable to expect a reduction in the rate of growth and a concomitant decrease in the rate of inflation without a slide into recession.

In the discussion of policy for the period immediately ahead, the members of the Committee agreed that, in seeking to achieve bank reserve and money market conditions broadly consistent with the longer-run ranges for monetary growth cited above, due regard should be given to the program for supporting the foreign exchange value of the dollar as well as to developing conditions in do" mestic financial markets and to uncertainties associated with the November 1 introduction of ATS. Against that background, the members differed somewhat in their views as to whether, and to what degree, additional firming in money market conditions should be sought during the next few weeks; no sentiment was expressed for easing money market conditions, As they had at the October meeting, moreover, most members favored giving greater weight than usual to money market conditions in the conduct of operations in the period before the next meeting, although some sentiment was expressed for a return to basing decisions for open market operations primarily on the behavior of the monetary aggregates.

With respect to the monetary aggregates, almost all members proposed that the Committee take account of the unusual uncertainties associated with the introduction of ATS in the same way that it had at the October meeting - namely, by giving primary emphasis to growth of M2 and by specifying only an upper limit, rather than a range, for growth of $\mathrm{M} 1$.

\section{Meeting Feld on December 19,1078}

The narrowly defined money supply (M1) declined at an annual rate of about $4 \frac{1 / 2}{2}$ percent in November. The contraction reflected, among other things, the shifts of funds from demand deposits to savings deposits associated with the introduction of the automatic transfer service (ATS) and effects of the substantial rise in shortterm market interest rates since April. Meanwhile, growth of M2 and M3 slackened further.

In subsequent weeks, newly available data led to progressively lower estimates of growth, and by the end of the first week in December the projections might, under normal circumstances, have called for a reduction in the objective for the Federal funds rate to $9^{3 / 4}$ percent. On December 8 , however, the Committee approved a recommendation by the Chairman to instruct the Manager to continue aiming for a Federal funds rate of $97 / 8$ percent during the period before the next regular meeting of the Committee, unless growth of the aggregates should appear to weaken significantly further.

The information reviewed at this meeting suggested greater strength in economic activity than had been evident at the time of the Committee's meeting a month earlier. . .

The growth of total credit at U.S. commercial banks was appreciably slower in November than in September and October. However, bank loans other than security loans continued to expand rapidly. To finance this expansion banks liquidated a sizable amount of security holdings and issued a substantial volume of large-denomination time deposits.

Most market interest rates rose further during the intermeeting period, as financial markets seemed to react to indications of continued strength in business conditions, added evidence of intense inflationary pressures, and the OPEC announcement of a large increase in oil prices.

In the Committee's discussion of the economic situation and outlook, most members expressed little or no 
disagreement with the staff projection of a gradual slowing of the expansion during 1979 and of a slight rise in the unemployment rate. At the same time, however, the observation was made that the latest information provided contradictory indications of underlying trends in economic activity and some members commented on the prospects for alternative courses of activity. The members continued to anticipate that average prices of goods and services would rise rapidly, and it was observed that the outlook for inflation had been worsened by the recent OPEC announcement of a substantial rise in oil prices during 1979.

Conceming the over-all situation, it was suggested on the one hand that the current and prospective pace of growth in activity was too rapid, that output was beginning to press against the limits of capacity, and that inflationary pressures - which for a long time had been greater than generally projected - were still increasing. An alternative appraisal of the latest data was that the strength in the current quarter, especially in consumer spending, most likely was an aberration - similar to others during the past few years - and that economic activity was remarkably well balanced for the present stage of the expansion. It was also suggested, however, that the strength in demands and activity, although possibly persisting for a quarter or two, might culminate in a recession for the second half of 1979 .

In the discussion of policy for the period immediately ahead, most members of the Commitiee advocated some additional firming in money market conditions. A few members preferred to direct operations toward maintaining the money market conditions currently prevailing. No member recommended an easing in money market conditions per se, but one suggested that whether money market conditions were firmed or eased be determined altogether on the basis of the incoming evidence on the behavior of the monetary aggregates.

Several reasons were advanced for some additional firming in money market conditions. Available economic data suggested that growth of output had not yet been slowed and that inflationary pressures remained intense. The strength of demands for bank loans and other credit seemed to provide a more reliable indication of underlying economic conditions than did the recent weakness of growth in the monetary aggregates. In any case, it was observed, weakness in monetary expansion following a long period of strong growth could be accepted for a time. Some additional firming in money market conditions, moreover, would help to maintain public confidence in the program to moderate inflation and to support the foreign exchange value of the dollar.

In support of the preference for maintaining prevailing money market conditions, rather than firming, it was ob. served that over the preceding 2 months the Committee had increased monetary restraint substantially. Because the evidence on current and prospective economic developments was conflicting, the Committee ought to pause and evaluate the effects of its recent actions before contemplating additional firming; if the unexpected shortfall in monetary expansion persisted, it might contribute to a recession. The uncertainties in the current situation also provided the grounds for the proposal to base the Committee's objective for money market conditions altogether or the incoming evidence on the behavior of the monetary aggregates: It was suggested that whether fundamental economic conditions were strong or weak would inevitably become evident in renewal of rapid monetary expansion or in continuation of sluggish expansion, leading in either case to appropriate objectives for money market conditions.

At the conclusion of the discussion the Committee agreed to instruct the Manager to direct open market operations toward raising the Federal funds rate to 10 percent or slightly higher. . . .

Subsequent to the meeting, on December 29, 1978, projections of growth in the monetary aggregates suggested that for the December-January period M2 would grow at an annual rate well below the lower limit of the 5 to 9 percent range specified by the Committee and that $\mathrm{Ml}$ would grow at a rate in the lower portion of its range of 2 to 6 percent. Since the meeting of the Committee on Decernber 19 the Manager had been aiming for a Federal funds rate of about 10 percent or slightly above, although Federal funds had been trading at higher levels in response to exceptional demands for excess bank reserves near the end of the year. The behavior of the aggregates would have called for a reduction in the objective for the funds rate toward the $9 \% / 4$ percent lower limit of its specified range. However, in view of uncertainties about the interpretation of the behavior of the aggregates at this time, and against the background of domestic and international economic and makket conditions, Chairman Miller recommended that the Manager be instructed to continue to aim for a Federal funds rate of 10 percent or slightly above, pending a review of the situation in the telephone conference, tentatively planned for January 12 . 